OCCASIONAL PAPER

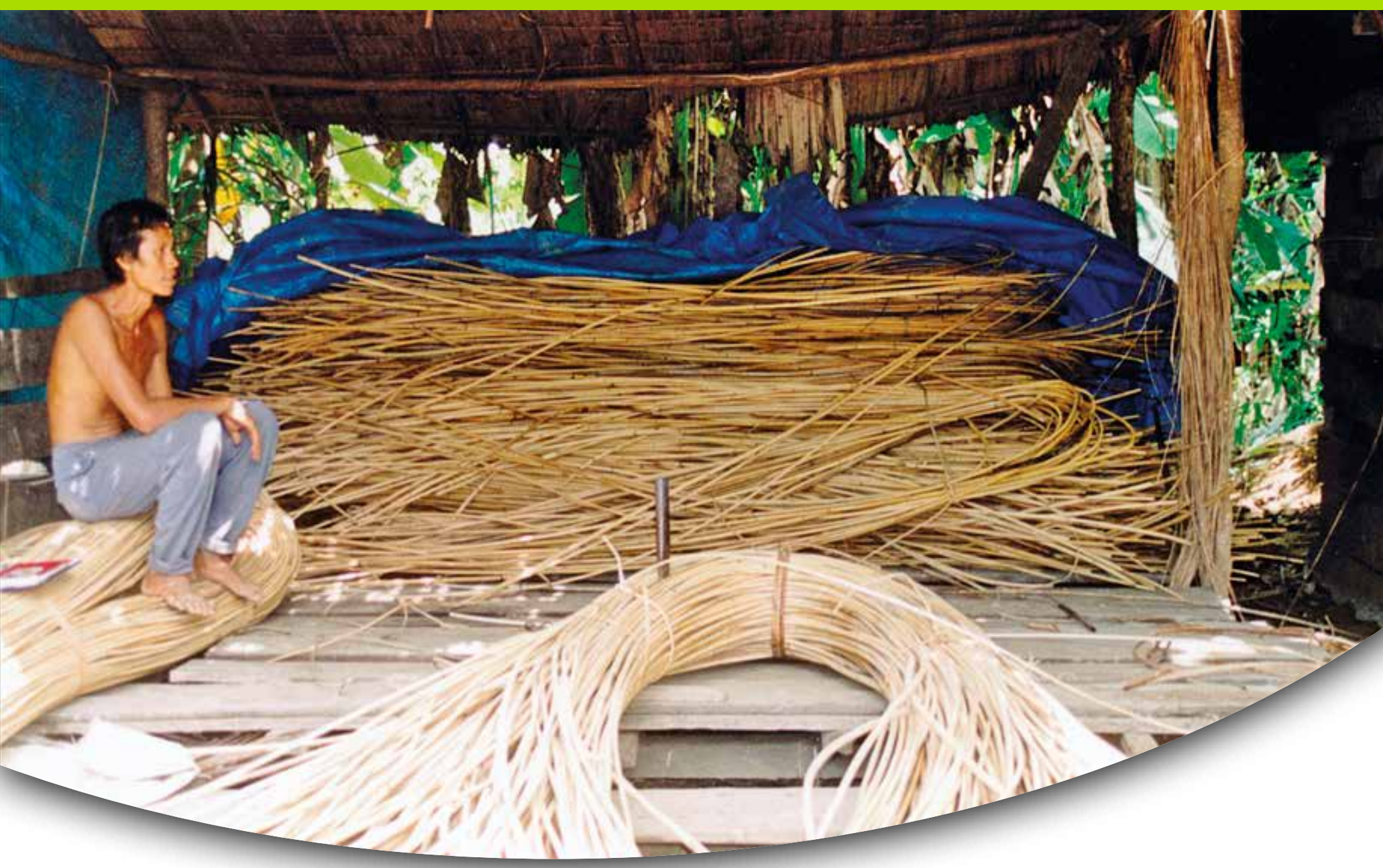

\title{
Rattan
}

\section{The decline of a once-important non-timber forest product in Indonesia}

Erik Meijaard

Ramadhani Achdiawan

Meilinda Wan

Andrew Taber

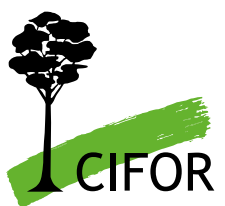





\section{Rattan}

\section{The decline of a once-important non-timber forest product in Indonesia}

Erik Meijaard

People and Nature Consulting International

Ramadhani Achdiawan

Center for International Forestry Research (CIFOR)

Meilinda Wan

Center for International Forestry Research (CIFOR)

Andrew Taber

The Mountain Institute 
Occasional Paper 101

(C) 2014 Center for International Forestry Research

Content in this publication is licensed under a Creative Commons Attribution-NonCommercial-NoDerivs 3.0 Unported License http://creativecommons.org/licenses/by-nc-nd/3.0/

ISBN 978-602-1504-28-4

Meijaard E, Achdiawan R, Wan M and Taber A. 2014. Rattan: The decline of a once-important non-timber forest product in Indonesia. Occasional Paper 101. Bogor, Indonesia: CIFOR.

Photo by Ramadhani Achdiawan/CIFOR

Rattan trader in West Kutai, East Kalimantan.

This report was commissioned by the Center for International Forestry Research (CIFOR) in support of its ongoing efforts to assess the impact of its research. The content consists of a review and compilation from published sources with some analysis and discussion by the primary writer (Erik Meijaard) and the supporting CIFOR team of Ramadhani Achdiawan, Meilinda Wan and Andrew Taber (formerly CIFOR, now with The Mountain Institute). Comments should be sent directly to emeijaard@gmail.com.

\author{
CIFOR \\ Jl. CIFOR, Situ Gede \\ Bogor Barat 16115 \\ Indonesia \\ $\mathrm{T}+62$ (251) 8622-622 \\ $F+62$ (251) 8622-100 \\ E cifor@cgiar.org
}

\title{
cifor.org
}

We would like to thank all donors who supported this research through their contributions to the CGIAR Fund. For a list of Fund donors please see: https://www.cgiarfund.org/FundDonors

Any views expressed in this book are those of the authors. They do not necessarily represent the views of CIFOR, the editors, the authors' institutions, the financial sponsors or the reviewers. 


\section{Table of contents}

Abbreviations $\mathbf{v}$

Acknowledgments $\quad$ vi

Executive summary $\quad$ vii

1 Indonesian rattan: A brief introduction 1

1.1 Trade 1

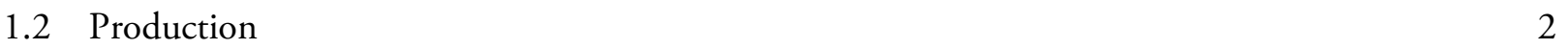

1.3 Rattan and forest 3

1.4 Rattan-related organizations in Indonesia 4

1.5 Rattan policy in Indonesia 4

2 Methodology 9

3 Summary of unstructured interview findings 11

4 Analysis of rattan trade volumes and values 14

5 A macroeconomic review of the rattan industry 18

6 Results from repeat interviews $\quad 24$

$\begin{array}{lll}6.1 & \text { Data quality } & 24\end{array}$

6.2 Impacts on local livelihoods based on repeat interviews 24

7 Discussion $\quad 26$

7.1 State of rattan in Indonesia 26

7.2 Socioeconomic impacts at the village level 29

7.3 The value of rattan production for forests and forest wildlife 29

8 Recommendations: Suggested follow-up activities 31

9 References

Appendix: Results from in-depth interviews 35 


\section{List of tables and figures}

\section{Tables}

1 Composition of rattan gardens in two locations (Modang and Rantau Layung) in East Kalimantan, compared with nearby natural forest.

2 Summary of ministerial decrees and regulations in Indonesia with relevance to the export of rattan. 5

3 Summary of interview results on the present state of rattan trade in Indonesia, major constraints and possible solutions.

4 Land sales by communities to coal mines in West Kutai, showing variation in land prices. 13

5 Quoted export prices of raw rattan from Indonesia. $\quad 17$

6 Model coefficients with dependent variable: Rattan price corrected by inflation. 23

7 Correlation coefficients between the variables used in the model to predict rattan farm-gate prices. 23

8 Cross tabulation of households with and without rattan gardens in 2004 and $2010 . \quad 24$

9 Cross tabulation of households with and without rubber gardens in 2004 and 2010.

10 Differences in income between 2004 and 2010 for households with or without rattan gardens. 25

11 Number of companies with a rattan export license in each province in Indonesia. 27

12 China's imports and exports of rattans for plaiting, rattan basketwork, bamboo and rattan furniture, rattan plaits, rattan plaited products, and bamboo and rattan chairs for 2008 .

\section{Figures}

1 Raw rattan prices paid to farmers (prices paid by traders in Damai Subdistrict) compared to value of rattan exports between 1985 and 2001.

2 Prices of wet and dry sega rattan along the market chain. 13

3 Total rattan exports from Indonesia (2002-2009). 14

$4 \quad$ Trends in export value and volume of semi and unprocessed rattan between 2002 and $2009 . \quad 15$

5 Indonesia's official trade partners for raw and semi-processed rattan. 16

6 Farm-gate prices of rattan in West Kutai in USD at average exchange rates for each year. $\quad 18$

7 Prices of unprocessed rattan and rice in West Kutai from 1984 to 2010 (in IDR). 19

8 Export volumes of rattan products in relation to export policy in Indonesia. 19

9 Total rattan exports from year to year in periods of total export bans of unprocessed and semiprocessed rattan, partial bans or free trade. 20

10 Export volumes of unprocessed and semi-processed rattan under different export policies. 20

11 Export of rattan furniture from Cirebon. 21

12 Rattan farm-gate prices under different trade policy conditions (a) in USD; and (b) in IDR. 22

13 Indonesian credit interest rates versus total export volumes of rattan products (with $95 \%$ confidence interval around linear fit).

14 The 2009 forest map for the West Kutai area, with orange polygons showing the locations of some rattan gardens mapped by SHK in 2004.

15 Rattan-splitting factory in Jengan Danum, West Kutai, with rattan--splitting machines in the background (February 2011).

\section{Boxes}

1 Quotes from interviews vii

2 SKAU (Letter of Origin) 37 


\section{Abbreviations}

AMKRI Asosiasi Mebel dan Kerajinan Indonesia (Indonesia Furniture and Handicraft Association)

APHI Asosiasi Pengusaha Hutan Indonesia (Indonesian Association for Forest Concessionaires)

APKINDO Asosiasi Panel Kayu Indonesia (Indonesian Wood Panel Association)

APRI Asosiasi Pengusaha Rotan Indonesia (Association of Indonesian Rattan Producers)

ASMINDO Asosiasi Industri Permebelan dan Kerajinan Indonesia (Indonesian Furniture Industry and Handicraft Association)

BPS Badan Pusat Statistik (Indonesian Bureau of Statistics)

CSF Center for Social Forestry (based at Mulawarman University, Samarinda, East Kalimantan, Indonesia)

Disperindag Dinas Perindustrian dan Perdagangan (Regional Office of Industries and Trade)

FAO Food and Agriculture Organization of the United Nations

FOB Free on Board price, generally meaning that the seller pays for transportation of the goods to the port of shipment, plus loading costs

GDP Gross Domestic Product

GIS Geographic Information System

GNI Gross National Income

HS Harmonized System

IDR Indonesian currency (rupiah)

IMF International Monetary Fund

INBAR International Network for Bamboo and Rattan

ITTO International Tropical Timber Organization

KBNK Kawasan Budidaya Non Kehutanan (forest estate land under non-forest use)

KpSHK Konsorsium Pendukung Sistem Hutan Kerakyatan (Consortium for the Support of Community Forest Systems)

NGO Non-governmental organization

NTFP Non-timber forest product

PPPR Perkumpulan Petani dan Pengrajin Rotan (Rattan Farmers and Craftsmen Association)

SHK Sistem Hutan Kerakyatan (see KpSHK)

SKAU Surat Keterangan Asal Usul (Letter of Origin)

USD US dollar

YRI Yayasan Rotan Indonesia (Indonesian Rattan Foundation) 


\section{Acknowledgments}

We thank the many people who gave up their time to provide information, principally through interviews, for this study. In addition, we are grateful for the support of the Australian National University, which enabled us to obtain information for this study by providing access to its electronic library. We are especially grateful to Brian Belcher for providing insights from his years working on rattan and for reviewing drafts of this report. We thank a CIFOR editor for substantially improving the text. 


\section{Executive summary}

Between 1997 and 2005, CIFOR and its research partners conducted studies on the role of nontimber forest products (NTFPs) in community livelihoods in East Kalimantan Province, Indonesia. One research component focused on the changing land-use dynamics and community livelihoods in a rapidly changing landscape. At that time, rattan was considered a good model NTFP - it had many of the characteristics typical of NTFPs, including the potential to cultivate it outside of a closed-canopy forest environment. In addition, global and domestic demand was high, prices were high and rattan was easy to produce.

The present study assessed the current status of the rattan industry in Indonesia, with a specific focus on West Kutai District, East Kalimantan, to review changes over time in rattan trade and community welfare. For this, we used a combination of a desktop study and in-depth interviews with 40 individuals who work in different sectors of the rattan market chain - from rattan harvesters and farmers to rattan furniture producers and exporters - to gain a better understanding of the rattan trade system in Indonesia. We also conducted repeat household livelihood surveys, which allowed us to assess how the role of rattan had changed over the previous seven years and how these changes were related to changes in household welfare. Finally, we conducted a multivariate time series analysis of a range of macroeconomic variables to determine which variables most strongly influenced rattan prices and trade volumes.

By the end of CIFOR's research in 2005, it had become clear that rattan was not going to be a major source of community income, and that non-forest cash crops such as rubber and oil palm would become more prominent sources of income. Our interviews in 2011 with individuals along the rattan supply chain confirmed that the rattan trade in Indonesia is very much reduced today. The main reason seems to be the low rattan prices at the farm gate. Farmers in CIFOR's former study sites prefer to invest their time and money in rubber and oil palm, or sell their land to any of the many coalmining and oil palm companies in the district.

\section{Quotes from interviews:}

A rattan farmer: "Although we are one
community here, even our brothers try to
steal our land to sell it to companies."
A rattan trader: "Morality has changed in
West Kutai with all the developments - it
is all money grabbing - rattan does not fit
anymore in that world."

A rattan intermediary: "Now the money is looking for rattan, whereas in the past rattan looked for money."

A Samarinda-based trader: "If the government does not get on top of oil palm and coal, rattan will be dead soon."

Repeat livelihood surveys in 2011, revealed that since 2004, the role of rattan as a source of community income had declined. Only $3 \%$ of households with rattan gardens actually obtained an income from rattan in 2010, compared with $8 \%$ in 2004 . Overall, nominal household incomes increased, for households with and without rattan gardens. The increases in nominal household incomes are statistically significant, but not when real incomes are calculated based on annual inflation rates.

An analysis of the rattan market chain and information from informants strongly suggests that rattan prices are kept artificially low through price fixing within a cartel of rattan traders, although no concrete evidence for such a cartel is available. Prices of rattan at the farm gate are also kept low by export quotas for unprocessed and semi-processed rattan, as well as the relative strength of the rupiah. International demand for Indonesia's raw rattan remains high. It appears, however, that export quotas and poor control of export volumes have resulted in significant levels of 
international smuggling of unprocessed and semiprocessed rattan.

Export volumes of Indonesian rattan products (as opposed to unprocessed and semi-processed rattan) are also in decline. The main reasons for this appear to be reduced overseas demand following the global economic crisis of 2008, the relative strength of the rupiah and the loss of Indonesia's competitive edge to other countries such as China. In addition, compared to its competitors, Indonesia reportedly has higher transaction costs, including taxes, tariffs, administrative costs and transportation costs, such as container handling.

Indonesia's policy on the export of raw and semiprocessed rattan has changed considerably over the past few decades from total trade bans at one extreme to unlimited trade at the other. Such policies appear to be strongly influenced by an oligopoly of rattan traders. Partial export quotas specified in a 2005 Ministerial Decree and the resulting restricted trade opportunities appear to be the main reasons why raw rattan prices remain low compared with other commodities and general inflation.

Policy discussions are hampered by a lack of information on rattan prices and trade volumes, the impact on the livelihoods of people in the rattan industry, and the number of people whose livelihoods (partly) depend on rattan. In addition, there is still significant uncertainty about the total area of planted and natural rattan-producing areas, with estimates in Indonesia varying by an order of magnitude. This uncertainty hampers efforts to develop sustainable management strategies and annual allowable harvest volumes. A possible role for CIFOR would be to provide scientific input into the development of a national rattan action plan. The International Tropical Timber Organization (ITTO) went some way toward this, but still relied on generally poor data. More accurate information on rattan trade, future development in the rattan products market, production capacity in forests and planted rattan gardens, and international trade, including illegal trade, is needed to better inform and guide rattan policies. The basic aim would be to determine which trade legislation would have the best macro and microeconomic results for Indonesia.

The Indonesian rattan industry as a whole could greatly benefit from a government roadmap that sets out the available rattan supplies, the needs of the domestic industry and the potential for exports of unprocessed and semi-processed rattan. The government could also be more proactive in promoting Indonesian rattan overseas and developing new markets, reducing production costs and administrative requirements, breaking up possible price cartels, and effectively monitoring exports to reduce smuggling.

Generally, the flow of information between rattan producers and domestic rattan consumers seems to be very poor. It might be worth investigating whether an online trading system could be developed to allow consumers and producers to communicate directly about volumes, specifications, prices and design trends. Such an investigation would also require a better understanding of the extent of price fixing and whether any effective cartels are operating within the Indonesian rattan industry.

This study has provided a rather unsophisticated economic analysis of how various macroeconomic variables affect rattan trade volumes and prices. A more robust analysis of the data might provide a more convincing tool to aid a revision of rattanrelated policies or provide more specific policy recommendations that can be discussed with rattan interest groups. 


\section{Indonesian rattan: A brief introduction}

Rattan (from the Malay rotan) is the collective name for the roughly 600 species of palms in the Calameae family. Most rattans are forest species. They are climbers that use thorny stems and leaves to hold on to the supporting structure of other plant species. They are cultivated either within forests or on swidden land, where rattan is planted after the first years of agricultural production and then grows along with the regrowing forest.

Rattan is used to make goods such as furniture for national and international markets. Rattans are generally lightweight, durable and - to a certain extent - flexible. The versatility of rattan in daily village life is tremendous (Weinstock 1983). Because of its flexibility and its long stems of great strength, rattan is a primary binding material. In its unsplit form, it is used to provide structural support in furniture and construction. Once split, rattan has a great variety of uses, including weaving into sleeping mats and baskets of all sizes and shapes and to make furniture. Increasingly, natural rattans are being replaced by synthetic rattans, especially in the use of outdoor furniture in temperate climates where natural rattans are subject to mold.

\subsection{Trade}

Worldwide, more than 700 million people reportedly trade in or use rattan (Sastry 2001). A decade ago, rattan was one of the main nontimber forest products (NTFPs) in international trade (Sastry 2001). Global trade in unprocessed and semi-processed rattan has been estimated at between 70,000 and 90,000 tons per year valued at between USD 50 million and 65 million (TradeData International 2005). In 2004, trade in rattan products, such as seats, basketwork and wicker products, was estimated at USD 892 million - or about 15 times the value of trade in unprocessed and semi-processed rattan (TradeData International 2005). By the time rattan products reach the customer, their value reportedly increases to an estimated USD 1.2 billion (Rattanland 2011). China and Hong Kong are the main importers, accounting for more than $90 \%$ of imports. Indonesia, Myanmar and Vietnam are the main suppliers of rattan.

Rattan became an important economic crop in Indonesia at the end of the 1960s with the growing motorization of river transportation and an increase in the number of traders and exporters (Pambudhi et al. 2004). In terms of export value, rattan became by far Indonesia's most important NTFP. Indonesian exports increased at least 200\% in the decade from 1968 to 1977 , with rattan generating more foreign exchange for Indonesia than any other forest product except timber (Peluso 1993). In the mid-1980s, the country was supplying between $75 \%$ and $90 \%$ of the world's markets (Peluso 1986; Mudhi 2008). At the time, most Indonesian rattan was sent to Singapore and Hong Kong, where it was used to manufacture furniture or simply cleaned and re-sorted to meet international trade standards, and re-exported to Europe, the United States or Japan (de Beer and McDermott 1996). As a result, Indonesia lost much potential revenue. For example, the value of Indonesian rattan after processing and reexport from Hong Kong in 1970 was 24-28 times the amount received by the original Indonesian exporters (Peluso 1986; de Beer and McDermott 1996). In 1997, Hong Kong imported USD 26 million worth of rattan to produce exports valued at USD 68 million, while in that same year Indonesia exported USD 15 million worth of rattan (Saragih 1996 in Mudhi 2008). There was a clear incentive for Indonesia to develop its own rattan products industry to increase the domestic value of rattan, thus allowing the country to compete more effectively with Hong Kong and Singapore. Another goal was to regulate its rattan resources better.

Until 1989, Indonesian rattan farmers and collectors profited from strong international demand for rattan, especially after competing 
countries such as Malaysia, Thailand and the Philippines banned the export of unprocessed rattan to increase in-country processing. Although the Indonesian government had discussed a similar step for years, the raw material could be exported until 1986. International trade in raw materials resulted in high incomes from rattan at the farm gate, but also in resource overexploitation and invasion by external collectors who did not recognize traditional land rights.

In 2008, Indonesia still accounted for about $80 \%$ of rattan on the global market, and was the leading exporter of rattan furniture and the second-largest exporter of rattan mats, plaits and basketwork (Hirschberger 2011). The main market was the European Union, which accounted for almost twothirds of Indonesian rattan furniture exports and half of basketwork exports. China is the biggest importer of unprocessed rattan from Indonesia. The rattan trade in Indonesia contributes about $6.5 \%$ of state revenue from all Indonesian industries related to forest products (ITTO 2007).

In the rattan market chain, as described by Belcher (1998), virtual integration is low, and raw rattan is produced in geographically dispersed areas. Quality varies considerably and a local rattan trader must visually inspect every rattan assignment, which is a costly process. Local traders often do not have the necessary business relationships with semi-processors or manufacturers, and probably cannot supply the volumes that they require. Business relationships are often based on family connections and ethnicity, so the barriers to entry may be very high (Belcher 1998). Along the rattan market chain, rattan changes ownership several times before it becomes an exportable product. Prices therefore increase significantly along the market chain from rattan collector and farmer to consumer. The value addition along the chain is obvious. Among the three main types of products, handicrafts account for the highest value addition (366\%), followed by mats (327\%) and furniture (273\%) (Purnama et al. 1998).

\subsection{Production}

In Indonesia, rattan is produced from wild, unmanaged resources on almost all major islands, including Sumatra, Java, Kalimantan, Sulawesi, the Moluccas, the south-central island region of
Nusa Tenggara and Papua. Rattan cultivation is much more restricted. Leading rattan-producing areas include Aceh, all provinces in Kalimantan, South, Central and Southeast Sulawesi and Papua (Kartodihardjo 1999). Estimates of the total area dedicated to rattan production in Indonesia vary considerably and should be used cautiously. Rombe and Malik (cited without reference in ITTO 2007) estimated the area of rattan production in natural forests in Indonesia at approximately 11.5 million ha. An estimate one order of magnitude lower than that was made by the Center for Statistics and Inventory of the Ministry of Forestry in 2004, which assessed the total area of natural forests that produced rattan as approximately $1,489,900$ ha (ITTO 2007). The total area of planted rattan in Indonesia was estimated at about 50,000 ha in 2000 (ITTO 2007).

In Kalimantan, rattan is usually planted in a traditional rice-swidden system. Rattans are ready for harvest 5-7 years after planting (personal communication from M. Stockdale). They are harvested by cutting the stems $1 \mathrm{~m}$ above the ground and pulling the climbers free from their tree supports. The stems are then cut into sections. In clustering species, the general harvesting cycle is 3-4 years, with each cluster of rattan stems yielding around $20-25 \mathrm{~kg}$. The harvest volume is limited to a farmer's carrying capacity of around $40-50 \mathrm{~kg}$. Processing small-diameter rattan involves a number of steps, some of which are done at the local production level and others further down the supply chain. After rattan farmers cut the rattan, remove the sheath and sort the harvest, middlemen then clean it by sanding and washing, after which the rattan is transported by river. Traders bleach the rattan by sulfurizing and drying, remove the nodes and grade it by type and quality. After this, the rattan is transported by sea to Java, where it is split into core and peel. Finally, the manufacturer uses the rattan for weaving and other products. The treatment of large-diameter rattan is similar, but with several additional processing steps (Haury and Saragih 1996).

Rattan production has long been a major source of income for large numbers of forest communities and local governments across Indonesia. Taxation data from 1844 suggest that rattan production in one area generated $85 \%$ of local taxes and thus very likely most of the monetary income for local 
communities (Schwaner 1853-1854). In the 1980 s and early 1990s, rattan farming was still the most important source of income for farmers in Central Kalimantan (Godoy and Ching Feaw 1991). For some villages in Central Kalimantan, rattan production contributed $90 \%$ of their cash income (Godoy and Ching Feaw 1989, 1991). During that period, rattan was just about the only NTFP to have a well-developed global market (Godoy 1990). For example, from 1982-1986, rattan accounted for about $75 \%$ of total NTFP exports for Indonesia (Miranda 1987), with the export of raw and semi-processed rattan generating USD 100 million (1990 price) (Godoy 1990). These export figures, however, underestimate the true economic value of rattan, because they ignore the value of rattan to local rural economies.

Estimates of the net annual income from rattan production vary widely, in the range of USD 7-224/ha/year (Priasukama 1989; Godoy and Ching Feaw 1991). Based on net present value and internal rate of return calculations in the late 1980s, it was estimated, using a real discount rate of $10 \%$, that smallholder cultivation of rattan would remain profitable if any of the following variables changed independently: the real discount rate doubled, the market land value increased fivefold, yields decreased by half, or farm-gate prices dropped by 35\% (Godoy 1990). However, more recent insights have questioned the profitability of rattan compared with other crops, primarily because of the relative decline in farmgate prices of rattan (Belcher et al. 2004b).

\subsection{Rattan and forest}

One of the reasons why rattan has been promoted as an important NTFP is the apparent species diversity associated with rattan gardens (Matius 2004; Pambudhi et al. 2004; Garcia-Fernandez and Casado 2005; Abrahamczyk et al. 2008; Watanabe and Suzuki 2008). For example, the structure of rattan cultivated in forests is often similar to that of neighboring forest, with comparable tree densities and species richness, although gardens have lower tree cover and a smaller basal area (Table 1). It is, however, difficult to generalize about the biodiversity values of rattan because the species grow and are cultivated under many different conditions. At one extreme, rattan planted on cleared land in a non-forest environment with a single species support stand (e.g., Artocarpus sp.) and frequently maintained will have low biodiversity values, possibly similar to those in monoculture plantations of oil palm (Elaeis guineensis), eucalypts or acacias. The other extreme is rattan in primary rainforest, where it grows naturally and is harvested only occasionally. Such rattan stands likely have high biodiversity values. The context of rattan cultivation is obviously important in determining its value for biodiversity conservation, and more studies of this subject in different rattan-growing contexts would be useful.

Table 1. Composition of rattan gardens in two locations (Modang and Rantau Layung) in East Kalimantan, compared with nearby natural forest.

\begin{tabular}{lccc} 
& \multicolumn{2}{c}{ Rattan gardens } & \multirow{2}{*}{ Mature forest } \\
\cline { 2 - 3 } & Modang & Rantau Layung & 83.9 \\
\hline Canopy cover (\%) & 57.7 & 76.2 & 560 \\
Density (trees/ha) & 530 & 503.5 & 23.5 \\
Basal area (m²/ha) & 12.5 & 14.7 & 22 \\
Tree richness (\# species/1000 $\mathrm{m}^{2}$ ) & 16.8 & 18.4 & 30 \\
Rattan density (canes/ha) & 2462.8 & 1065.3 & 0 \\
Commercial rattan density (canes/ha) & 507.8 & 227.1 & \\
Garden age (years) & 25.6 & 33.1 & \\
Labor allocation (person days/ha year) & 11.3 & 6.4 & \\
\hline
\end{tabular}

Source: Garcia-Fernandez and Casado (2005) 


\subsection{Rattan-related organizations in Indonesia}

Rattan furniture producers are coordinated through several umbrella organizations. The largest of these is the joint marketing board of the Indonesian Furniture Industry and Handicraft Association (Asosiasi Industri Permebelan dan Kerajinan Indonesia - ASMINDO). ASMINDO was established in August 1988 by Mohamad "Bob" Hasan, a close partner of the then Indonesian President Suharto. Hasan controlled numerous timber and related associations, including the Indonesian Wood Panel Producers Association (Asosiasi Panel Kayu Indonesia APKINDO), Nippindo, the Indonesian Loggers' Association (APHI) and the Indonesian Forestry Community. Because of its association with Hasan, ASMINDO was often referred to as the "rattan cartel". ASMINDO operates as a policy platform for a handful of large furniture exporters (von Luebke 2009) and plays an important role as the official furniture body responsible for maintaining regular dialogue with government and for consultation with government agencies and domestic and international private sector representatives. ASMINDO has lobbied vigorously for the interests of rattan furniture manufacturers at the national level by opposing government policy that allows the export of unprocessed and semi-processed rattan. Such exports benefit raw material producers, collectors and traders, but are perceived as a threat by the furniture manufacturers, because Indonesia's potential added value of raw material is transferred to competitors in China, Vietnam and other countries (Aryasena Wicker Furniture 2010). According to Belcher (1998), the quality and volume restrictions that ASMINDO imposed on the export of rattan mats (lampit) had a severely negative impact on the size of the manufacturing industry and hence on demand and prices for raw and semi-processed rattan throughout the system. The Indonesian Rattan Furniture and Craft Producers Association (AMKRI) is another organization focused on the furniture side of the rattan industry, with a general mission to promote the Indonesian rattan industry and stimulate innovation. A third rattan organization is the Association of Indonesian Rattan Producers (Asosiasi Pengusaha Rotan Indonesia - APRI), which mostly represents rattan traders and middlemen; APRI split off from ASMINDO in 2004. APRI has been a vocal opponent of any rattan export restrictions, arguing that such restrictions negatively affect the livelihoods of rattan farmers and smaller traders.

On the rattan production side, the Consortium for the Support of Community Forest Systems

(Konsorsium Pendukung Sistem Hutan Kerakyatan - KpSHK/SHK) is one of the stronger community-focused groups, and is affiliated with a range of other production support groups (listed on their website: http://en.kpshk. org/). The Indonesian Rattan Foundation (Yayasan Rotan Indonesia - YRI) is another organization that supports the production side of the rattan industry. It generally supports the removal of all export bans, quotas and tariffs, and has asked the government to slow down the development of a synthetic rattan industry.

\subsection{Rattan policy in Indonesia}

Indonesia has a tradition of heavy government intervention in resource industries, often in collusion with powerful private interests (de Jong et al. 2003; Pambudhi et al. 2004). The rattan boom in the 1970s and 1980s attracted the Government's attention, and a series of regulations were put in place to capture some of the profits and to regulate the industry and trade (see Table 2 for an overview). The first such restriction was announced in 1979 , with a view to generating more foreign income by increasing the international market share and protecting national supplies of rattan (Mudhi 2008). This followed bans on the export of roundwood logs, which similarly aimed at increasing Indonesia's capacity to develop a national wood and wood products industry (Tambunan 1995).

In 1979, the Indonesian government restricted the export of unprocessed rattan and then semi-processed rattan as a way of supporting the development of national rattan industries (Achdiawan and Belcher 2005). This policy (later replaced with a prohibitive export tariff) was in place for almost 20 years; a similar policy was implemented by other rattan-producing countries around the same time (Malaysia, except Sarawak and Sabah, Thailand [around 1978] and the Philippines [around 1978]) (de Beer and McDermott 1996). The government policies benefited the domestic processing industry and monopsonistic manufacturing associations (Belcher et al. 2004a), but during this period 
Table 2. Summary of ministerial decrees and regulations in Indonesia with relevance to the export of rattan.

\begin{tabular}{|c|c|c|}
\hline Year & Ministerial decrees & Relevance to rattan trade \\
\hline 1979 & $\begin{array}{l}\text { Decree of Minister of Trade and } \\
\text { Cooperative No. } 492 / \mathrm{Kp} / \mathrm{VII} / 1979\end{array}$ & $\begin{array}{l}\text { Prohibited exports of any unprocessed rattan originating in } \\
\text { Indonesia }\end{array}$ \\
\hline 1988 & $\begin{array}{l}\text { Decree of Minister of Trade No. } \\
274 / \mathrm{Kp} / \mathrm{X} / 86 \text {, and Decree of } \\
\text { Minister of Trade } 1907 \mathrm{KP} / \mathrm{VI} / 88\end{array}$ & $\begin{array}{l}\text { Prohibited exports of raw and semi-finished rattan from } \\
\text { Indonesia }\end{array}$ \\
\hline 1992 & $\begin{array}{l}\text { Minister of Trade Decree } \\
\text { No. } 179 / \mathrm{Kp} / \mathrm{VI} / 92\end{array}$ & $\begin{array}{l}\text { Canceled decrees No. } 492 / 1979 \text { and No. } 274 / 86 \text {, to allow the } \\
\text { export of raw and semi-finished rattan and rattan products, but } \\
\text { with an export tariff of USD 15/kg for unprocessed, washed, } \\
\text { smoked or sulfurized rattan, and USD } 107 / \mathrm{kg} \text { for polished rattan, } \\
\text { rattan core and peel, and rattan webbing (Mudhi 2008). }\end{array}$ \\
\hline 1996 & $\begin{array}{l}\text { Decree of Minister of Trade } \\
\text { No. 666/KMK/017/1996 }\end{array}$ & Canceled export tariffs of 1992 \\
\hline 1998 & $\begin{array}{l}\text { Decree of Minister of Trade } \\
\text { and Industry No. 440/MPP/ } \\
\text { Kep/4/1998; SK No. 410/Kp/ } \\
\text { XII/1988; and Decree of Minister } \\
\text { of Trade and Industry No. 33/ } \\
\text { Mpp/Kep/1998 }\end{array}$ & $\begin{array}{l}\text { Following the Asian economic crisis and IMF intervention } \\
\text { in Indonesia, many export restrictions were lifted. } \\
\text { Various decrees allowed the export of dried, round } \\
\text { rattan (rotan bulat) and rattan mats. Trade was relatively } \\
\text { unrestricted between 1998-2004. }\end{array}$ \\
\hline 2004 & $\begin{array}{l}\text { Decree of Minister of Trade } \\
\text { and Industry No.355/ MPP/ } \\
\text { Kep/5/2004 }\end{array}$ & $\begin{array}{l}\text { Prohibited the export of raw rattan and rattan from natural } \\
\text { forest, but allowed the export of cultivated sega rattan (Calamus } \\
\text { caesius) and irit rattan (Calamus trachycoleus) with a diameter of } \\
4-16 \mathrm{~mm} \text {. This decree also allowed the export of rotan bulat and } \\
\text { polished rattan, including semi-finished rattan core and peel. }\end{array}$ \\
\hline 2005 & $\begin{array}{l}\text { REGULATION OF THE MINISTER OF } \\
\text { TRADE No. 12/M-DAG/PER/6/2005 }\end{array}$ & $\begin{array}{l}\text { Allowed the export of some types of rattan, but capped it } \\
\text { at } 25,000 \text { tons of raw rattan per year, } 16,000 \text { tons of semi- } \\
\text { finished rattan produced from sega and irit plants per year, and } \\
36,000 \text { tons per year of semi-finished rattan produced from } \\
\text { other plants. }\end{array}$ \\
\hline 2008/2009 & $\begin{array}{l}\text { REGULATION OF THE MINISTER } \\
\text { OF TRADE No. 28/M-DAG/ } \\
\text { PER/7/2008; REGULATION OF } \\
\text { THE MINISTER OF TRADE No. } \\
\text { 33/M-DAG/PER/7/2009 and } \\
\text { REGULATION OF THE MINISTER OF } \\
\text { TRADE No. 36/M-DAG/PER/8/2009 }\end{array}$ & $\begin{array}{l}\text { These policies reiterated the } 2005 \text { quotas, but required rattan } \\
\text { producers from Kalimantan and Sulawesi to supply } 70 \% \text { of } \\
\text { their production to the local market, with the remaining } 30 \% \\
\text { for export. Producers from outside these areas were prohibited } \\
\text { from exporting raw rattan; only semi-finished sega and irit } \\
\text { rattan of specific diameters could be exported. }\end{array}$ \\
\hline $2011^{\mathrm{a}}$ & $\begin{array}{l}\text { REGULATION OF THE MINISTER } \\
\text { OF TRADE OF THE REPUBLIC } \\
\text { OF INDONESIA No. 35/M-DAG/ } \\
\text { PER/11/2011 }\end{array}$ & $\begin{array}{l}\text { Completely banned the export from Indonesia of raw rattan, } \\
\text { round rattan, washed/sulfurized rattan and semi-finished rattan }\end{array}$ \\
\hline
\end{tabular}

See the Addendum to this report for additional policy changes in 2011.

rattan producers suffered severe price declines to the point that many productive rattan gardens were abandoned (see review of market trends in Figure 1). The government also lost out on received economic rent (Mudhi 2008). The rattan-processing industry gained from short-term low prices, and from reduced availability and/or higher prices of raw material, compared to their competitors (Achdiawan and Belcher 2005).

In the mid-1980s, the Indonesian Ministry of Forestry appraised the total annual Indonesian rattan production in 20 provinces to be between 80,000 and 100,000 tons, although other sources 


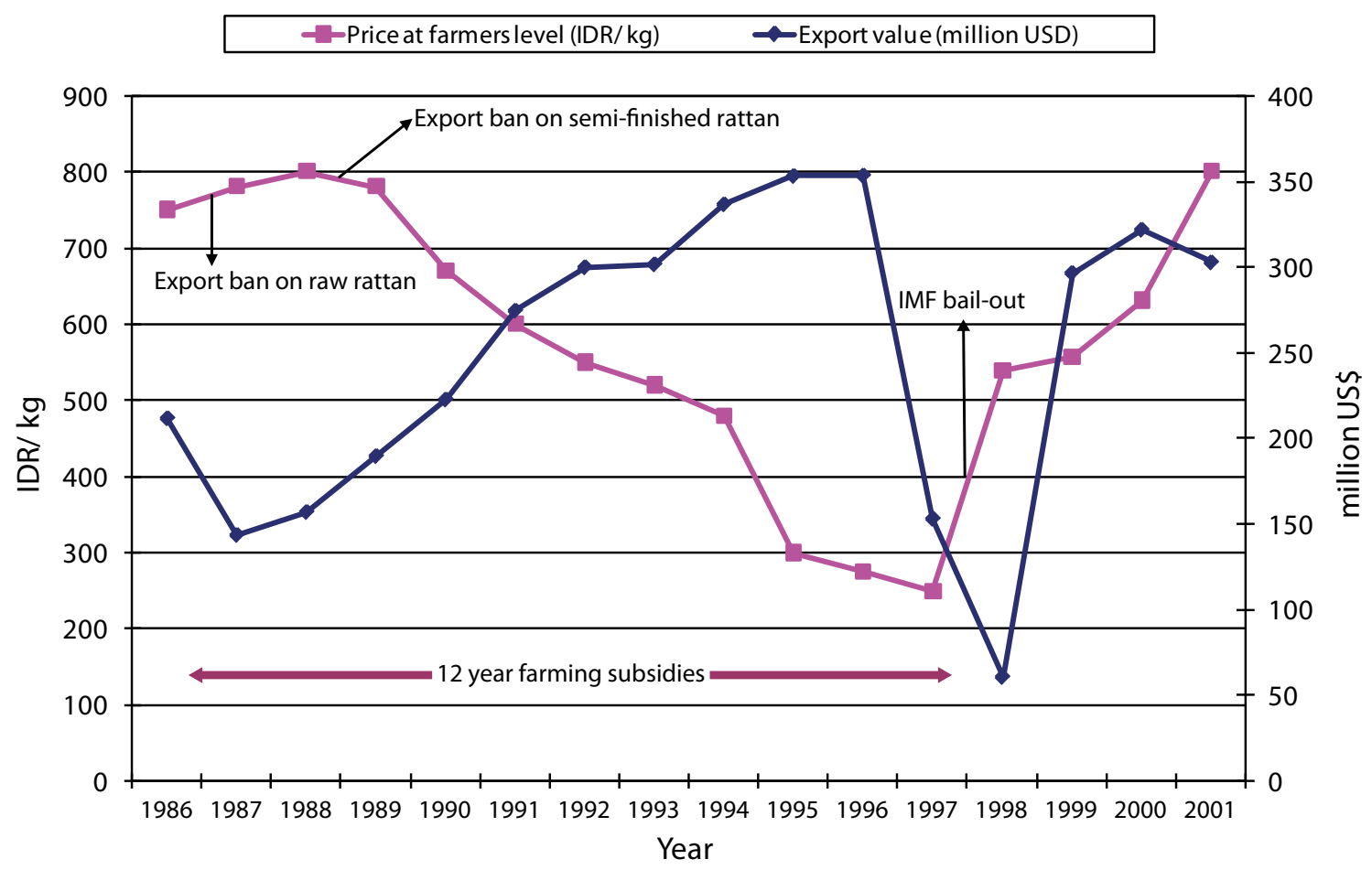

Figure 1. Raw rattan prices paid to farmers (prices paid by traders in Damai Subdistrict) compared to value of rattan exports between 1985 and 2001

Source: Unpublished data generated by CIFOR in 2002.

estimated the total annual production potential to be at least 250,000 tons (PT Capricorn Indonesia Consult Inc. 1988). At that time, Indonesia accounted for $75.5 \%$ of global rattan production, followed by the Philippines, Thailand and Malaysia. Nevertheless, Indonesia was lagging behind many countries in terms of international trade and production of rattan products. Even countries without their own rattan resources, such as Hong Kong, Taiwan, South Korea and Italy, had bigger markets for rattan products than Indonesia (PT Capricorn Indonesia Consult Inc. 1988).

The apparently low added value of Indonesia's rattan industry led to a decision by the Indonesian government in October 1986 (Ministry of Trade and Industry No. 274/KP/X/1986) to ban the export of raw rattan (washed and sulfurized, split and roughly polished) and phase out the export of semi-finished rattan products (such as finely polished rattan) as of 1 January 1989 (Purnama et al. 1998). This decision was widely criticized because it assumed that Indonesia could quickly develop its own rattan products industry to cater to overseas market demand and tastes. The government decision led to a rapid increase in the export of semi-finished rattan products and stockpiling of raw rattan in consumer countries to beat the ban (PT Capricorn Indonesia Consult Inc. 1988; Safran and Godoy 1993). In Kalimantan, prices and rural incomes dropped and rattan cultivation slowed or stopped altogether, with farmers switching to or intensifying other activities (Safran and Godoy 1993). From 1986 to 1997, raw rattan prices at the farm gate fell from about IDR $750 / \mathrm{kg}$ to IDR $250 / \mathrm{kg}$ even while the value of total rattan exports tripled. The Indonesian ban also caused world prices to increase by $20 \%$ (Godoy and Rodrik 1989). Seeing that the policy had thus had the opposite effect to what was intended, in 1992, the government raised the export check prices of rattan (on which export taxes are calculated), with some taxes increasing by nearly $200 \%$. This reduced Indonesia's exports of unfinished rattan, while the export of rattan products kept increasing. Gunawan (2002) showed how the export bans led to an increase in raw rattan supply and a decrease in prices, harming local farmers and collectors. Although the government subsequently lifted the export ban on semi-finished products in 1992 through Ministry 
of Trade and Industry No. 179/ KP/VI/92 on

"Rattan export regulation", the prohibitive export tax continued to virtually prevent such exports (Purnama et al. 1998).

Following the 1997 economic crisis, the International Monetary Fund (IMF) imposed strict conditions on loans designed to help Indonesia recover. The IMF program in Indonesia included major reforms of domestic and foreign trade and related policies, most of which were completed or at least in the works before President Suharto stepped down in May 1998. Export taxes for products such as logs and rattan were reduced as a means of boosting their export (Marks 2009). The crisis and subsequent policy changes caused major changes in rattan prices (Figure 1). Non-governmental organizations (NGO) called for the breakup of ASMINDO, the plywood cartel APKINDO, and its Indonesian/Japanese counterpart NIPPINDO, all controlled by Bob Hasan (Fried and Rich 1998). ASMINDO was allowed to continue its activities, albeit without the leadership of Bob Hasan.

In 2004, under the Megawati government, a new set of rattan-related policies was introduced. The then Minister of Trade and Industry, Rinus Wandi, introduced a new rattan export ban (Keputusan Menteri Perindustrian dan Perdagangan Republik Indonesia Nomor: 355/ $\mathrm{MPP} / \mathrm{Kep} / 5 / 2004)$. Allegedly, this decision had a politically opportunistic element, seeking to boost President Megawati's chances of reelection: $30.6 \%$ of the Cirebon electorate (where the rattan furniture industry is very important) that year voted for Megawati's political party (Kompas 2011).

Following consultation with CIFOR and other rattan stakeholders, the then Minister of Trade and Industries Mari Pangestu revised the 2004 export ban in May 2005 (Permendag No.12/2005). That decree changed the export ban into a set of quotas for selected rattan species of certain dimensions and certain degrees of processing (washing and sulfurizing or polishing). Again, political interests appeared to be at play, with Jusuf Kalla, the then Vice-President in the Yudhoyono government, working toward a removal of the ban to stimulate rattan exports from his home area of Sulawesi (Kompas 2011).
According to ASMINDO, the 2005 export quotas and the partial lifting of the export ban on raw and semi-processed rattan hurt the Indonesian rattan industry. The chairman of the Cirebon ASMINDO claimed that the decline in furniture exports from Cirebon following the 2008/2009 economic crisis was caused in part by the 2005 decree (SK No. 12), which he said allowed the free export of unprocessed rattan to countries that were highly competitive in wood and rattan furniture, such as China and Vietnam (Rukmana 2005; Tambunan 2009). The chairman claimed that this policy not only caused a scarcity of raw materials in local markets for domestic furniture producers, but also made it more difficult for domestic producers to compete with China's and Vietnam's furniture industries (Tambunan 2009). Apparently, 32,000 rattan workers in the Cirebon area were laid off in 2005 after rattan exports fell by $60 \%$ because of tough competition from Vietnam and China, which could buy cheap raw and semi-finished rattan and produce cheaper rattan furniture than in Indonesia (Rukmana 2005). Similar figures were reported by AMKRI in late 2008, with estimates that the rattan industry had laid off some 35,000 workers because of deteriorating economic conditions (Gunawan and Siregar 2009).

The changes in export volumes from Indonesia and rattan prices were related not only to Indonesian policies. For example, in August 2004, Vietnam, a major rattan-producing country, prohibited nearly all rattan exports. This probably contributed to the substantial jump in the volume of exports from Indonesia as well as the increase in the average prices paid for rattan (TradeData International 2005). Similar to Indonesia, Vietnam has gone through a series of export bans, partial bans and free trade options with the same goal of strengthening the local furniture-production industry (Quang 2004).

In 2008 and 2009, the Indonesian government released further rattan policies (Table 2), which limited Indonesia's exports of semi-finished rattan to 35,000 tons per year. APRI protested strongly, saying that Indonesia consumed only 40,000 tons of rattan per year while it could potentially produce 696,000 tons of natural rattan annually. The export restrictions eventually caused an oversupply of rattan in the country (Jakarta Post 2010). Lisman Sumardjani, chairman of the 
Indonesian Rattan Foundation, calculated that Indonesia could earn USD 1.8 billion per year if rattan were exported as half-finished products. $\mathrm{He}$ said that the oversupply had reduced rattan prices: "The price of one kilogram of rattan used to equal three kilograms of rice, ..... but now one kilogram of rattan is equal to 250 grams of rice or $\operatorname{Rp} 1,500$ [16 US cents]" (Jakarta Post 2010).

Most recently, in February 2011, the Indonesian Ministry of Trade further reduced the export quotas for the period January to March 2011, with a view to forcing raw rattan exporters to increase their supply to domestic manufacturers (Kandi 2011). APRI again protested, saying that domestic demand was much reduced and that rattan traders could not sell their rattan domestically. On the other hand, international demand for rattan was high with many importers asking for raw rattan, but Indonesia's exporters had reached their quotas and could not fulfil international demand.
Finally, in October 2011, Gita Wirjawan was chosen by President Susilo Bambang Yudhoyono to replace Mari Pangestu as Minister of Trade. Within a month of assuming his new position, the new Minister of Trade proposed major policy changes for rattan trade. The resulting new regulations are:

1. Ministry of Trade Regulation No. 35/M-Dag/ PER/2011: Raw Rattan Export Ban

2. Ministry of Trade Regulation No. 36/M-DAG/PER/2011: Rattan Inter Island Trade Regulation

Trade Regulation No. 35/M-Dag/PER/2011 completely banned the export from Indonesia of raw rattan, round rattan, washed/sulfurized rattan and semi-finished rattan. This effectively reinstated the laws that were in place from 1979 to 1992 and in 2004 . 


\section{Methodology}

The present study analyzes the Indonesian rattan industry, the relationship between rattan production and deforestation and forest degradation, and the role of the industry in local livelihoods. A detailed analysis was conducted in West Kutai District, East Kalimantan, Indonesia. In this same area, CIFOR had previously conducted household livelihood surveys, on rattan farming, in this same area.

We interviewed 40 people along the Indonesian rattan market chain, including rattan collectors, rattan farmers, rattan traders, general local traders, regional traders, Java-based traders and exporters, and Java-based rattan furniture and handicraft producers. Our list of interviewees also included people from local governments and NGOs. These discussions were unstructured and generally covered the status of rattan trade, rattan research and rattan policies (see Appendix for names of interviewees).

In addition to these interviews, we contacted 15 rattan importers (Singapore, China, Europe, USA, Canada and South Africa), which we randomly selected based on availability of email addresses following a web search. Via email, we asked these rattan importers several questions regarding the country(s) from which they import rattan and rattan products, the percentage of rattan coming from Indonesia and China, and any particular difficulties that arise when trading with Indonesia.

To determine the influence of rattan production on the welfare and livelihoods of communities, and the general trends in rattan production in West Kutai, we conducted interview surveys among rural communities in the district. We designed these interview surveys so that the results could be compared to surveys conducted by CIFOR and the Center for Social Forestry (CSF) in 2004 (see Dewi et al. 2005), and provide insight into the changes that have occurred in households that produce rattan compared with those that do not since the 2005 government policy on rattan exports.
During the 2004 surveys, 859 people were interviewed in 43 villages, 155 of whom reported obtaining income from rattan production. We used the random selection function in Microsoft Excel to generate a $20 \%$ random subsample of the 704 non-rattan-growing respondents, and merged the remaining respondents with the rattan-producing respondents. We deleted several villages for which only one or two respondents had been selected, because of the relative effort it would require to visit these villages to talk to only one or two respondents. The resulting file contained 224 respondents whom we wanted to interview again. We assumed that the chance of encountering these people again were about $50 \%$ (with former respondents having left the village, or being otherwise unavailable for repeat interviews). The minimum target was 125 respondents, of which about half would have been rattan producers in 2004.

The repeat interviews were conducted by a team of interviewers from CSF. They were given a questionnaire that was based on a subset of questions from the original 2004 surveys (see Appendix). These questions were selected according to their relevance to rattan production versus other crops, and household welfare, income and expenditures. We also inserted specific questions regarding the rattan trade, and whether the respondents were still maintaining rattan gardens.

During her field visit, Meilinda Wan (MW) accompanied the CSF interviewer to judge the reliability of the interview methods. She also crosschecked previous interviews by going back to three households and redoing the surveys to see if any important information had been left out.

To assess the relationship between various rattan metrics such as farm-gate price, Indonesian export volumes and a range of macroeconomic variables, we compiled various datasets from the World Bank database (2011) for statistical analysis, as well as 
the data on rattan trade from UN Comtrade and Statistics Indonesia (BPS). These included the following:

- Trade volumes of rattan products under different harmonized system (HS) trade codes

- Indonesia's gross domestic product (GDP, current USD): 1984-2009

- Indonesia's exports of goods and services (\% of GDP): 1984-2009

- Indonesia's GDP per capita (current USD)

- Indonesia's gross national income (GNI) in purchasing power parity dollars

- Indonesia's inflation, consumer prices (annual \%)

- Credit interest rates

- Exchange rate of IDR to USD

- Total rattan exports

- Rattan exports to Japan

- Rattan exports to China.

Most macroeconomic factors were downloaded from the World Bank economic database. Credit interest rates for 1986-2008 were obtained from Putra (2010). Exports to Japan and China were obtained from the Asian Development Bank database (ADB 2009). Estimates of rattan, rubber and rice prices in West Kutai were obtained from previous CIFOR research in the area, updated by our own information gathered during field surveys.

One problem with analyzing rattan trade volumes is that the HS-coding system used in Indonesia generally does not distinguish between natural and synthetic rattan products, as a government official in Cirebon admitted. This makes it hard to determine the exported volumes of natural rattan products. Using information from traders, we corrected trade volumes with a linearly increasing percentage of synthetic rattan in the total volume of $1 \%$ in 1998 to $25 \%$ in 2010.

We generated simple bivariate statistics to analyze the relationships between different variables. In addition, we conducted several statistical multivariate time series analyses to study the impact of export policies on rattan prices and export volumes in comparison with the impact of macroeconomic variables. Our main purpose was to better understand the impact of policy on rattan prices and thus, indirectly, on the income that rattan growers derive from rattan cultivation. This approach would clarify whether the policy recommendations that CIFOR gave were aligned with the organization's goal of contributing to a reduction in both poverty and deforestation. 


\section{Summary of unstructured interview findings}

The interviews with people from along the rattan market chain provided a generally dichotomous view of the rattan trade, its main constraints and possible ways to reduce those constraints (Table 3; for detailed interview results, see Appendix). On the one hand, people in the rattan-producing areas of Kalimantan (and presumably Sulawesi and Sumatra) are in favor of opening all exports of rattan, as they believe that this would lead to higher international demand and higher prices. They claim that Indonesia has enough rattan to supply both the international and domestic markets, but buyers have to pay the right price. These views are supported by organizations such as SHK and APRI. On the other hand, the furniture industry in Java sees the present export of unprocessed and semi-processed rattan as one of the main reasons for the slump in the rattan

Table 3. Summary of interview results on the present state of rattan trade in Indonesia, major constraints and possible solutions. Note that national government authorities were not interviewed for this study.

\begin{tabular}{llll}
\hline $\begin{array}{l}\text { Position in rattan } \\
\text { market chain }\end{array}$ & $\begin{array}{l}\text { Perception of rattan } \\
\text { production and trade }\end{array}$ & $\begin{array}{l}\text { Main constraint in rattan } \\
\text { markets }\end{array}$ & $\begin{array}{l}\text { Possible solutions suggested by } \\
\text { interviewees }\end{array}$ \\
\hline Proponents of lifting the export ban on unprocessed and semi-processed rattan
\end{tabular}


Table 3. Continued

\begin{tabular}{|c|c|c|c|}
\hline $\begin{array}{l}\text { Position in rattan } \\
\text { market chain }\end{array}$ & $\begin{array}{l}\text { Perception of rattan } \\
\text { production and trade }\end{array}$ & $\begin{array}{l}\text { Main constraint in rattan } \\
\text { markets }\end{array}$ & $\begin{array}{l}\text { Possible solutions suggested by } \\
\text { interviewees }\end{array}$ \\
\hline \multicolumn{4}{|c|}{ Proponents of banning all exports of unprocessed and semi-processed rattan } \\
\hline $\begin{array}{l}\text { Rattan traders in } \\
\text { Java }\end{array}$ & $\begin{array}{l}\text { Decline in furniture } \\
\text { trade because of } \\
\text { exchange rate, high } \\
\text { price of oil, competition } \\
\text { from China, and export } \\
\text { quotas. }\end{array}$ & $\begin{array}{l}\text { Export quotas provide cover } \\
\text { for smuggling unprocessed } \\
\text { rattan and give China } \\
\text { opportunities to gain from } \\
\text { Indonesian rattan. }\end{array}$ & $\begin{array}{l}\text { Export of semi and unprocessed } \\
\text { rattan should be completely } \\
\text { banned. }\end{array}$ \\
\hline $\begin{array}{l}\text { Furniture } \\
\text { producers }\end{array}$ & $\begin{array}{l}\text { Suffering from reduced } \\
\text { demand and lack of } \\
\text { rattan supply. }\end{array}$ & $\begin{array}{l}\text { Export quotas direct } \\
\text { Indonesian rattan to } \\
\text { overseas competitors; rupiah } \\
\text { is too expensive. }\end{array}$ & $\begin{array}{l}\text { Ban all exports and make } \\
\text { Indonesian rattan more } \\
\text { competitive. }\end{array}$ \\
\hline $\begin{array}{l}\text { Local } \\
\text { government in } \\
\text { Java }\end{array}$ & $\begin{array}{l}\text { The Furniture industry } \\
\text { is negatively affected } \\
\text { by the export quotas } \\
\text { and smuggling. }\end{array}$ & $\begin{array}{l}\text { Price fixing, poor } \\
\text { government supervision of } \\
\text { trade and export, and a lack } \\
\text { of information flow. }\end{array}$ & $\begin{array}{l}\text { A complete export ban on } \\
\text { unprocessed and semi-processed } \\
\text { rattan should stimulate the } \\
\text { furniture market. }\end{array}$ \\
\hline ASMINDO & $\begin{array}{l}\text { The Rattan industry is } \\
\text { in very bad shape. }\end{array}$ & $\begin{array}{l}\text { Export quotas are to } \\
\text { blame, as they lead to } \\
\text { smuggling. Not enough } \\
\text { international promotion of } \\
\text { Indonesian rattan. }\end{array}$ & $\begin{array}{l}\text { All exports of unprocessed and } \\
\text { semi-processed rattan should } \\
\text { be banned. }\end{array}$ \\
\hline
\end{tabular}

furniture business and calls for a complete ban on exports. This view is supported by ASMINDO and the Ministries of Industry and Forestry.

One interesting aspect that emerged from the interviews is that rattan farmers now have multiple possible sources of income, which has reduced their reliance on rattan compared to 15 years ago when CIFOR's work commenced. Products such as rubber and oil palm, gold in Sulawesi, provide lucrative alternatives to rattan. In West Kutai, rattan farmers can also earn significant cash from selling their land to either oil palm companies or mining operations. In the late 1990s, rattan farmers in Kutai District owned an average of 10.9 ha of land (Purnama et al. 1998). Land prices in coal-mining concessions in West Kutai vary considerably from IDR 3,000,000/ha (the lowest sale price mentioned in an interview) to IDR 180,000,000/ha (Table 4). Oil palm plantations pay considerably less (IDR 400,000/ ha was mentioned by one interviewee), but the sales agreement allows farmers to retain $20 \%$ of the land for their own oil palm cultivation. Assuming that farmers, with land overlying significant coal deposits, sell all their 10.9 ha of land, they could on average earn between about IDR 30 million (USD 3,370) and IDR 1.8 billion (USD 200,000). Selling their 10.9 ha of rattan land to oil palm plantations would generate about IDR 4 million. However, with average earnings from smallholder oil palm cultivation reportedly at IDR 2 million/ha/month, farmers could earn some IDR 48 million per year after about three years when the palms become productive, minus the costs of seedlings and fertilizer, and without taking a discount rate into consideration.

The Indonesian government must consider these new opportunities for farmers if it is serious about maintaining a viable rattan industry. As long as other land uses provide farmers with more cash than rattan does, they are unlikely to harvest much rattan and even less likely to invest in developing rattan gardens.

Many interviewees suggested that there are cartels in the rattan industry that engage in illegal or semi-legal practices such as price fixing, controlling industry output and internally arranging market shares and allocation of customers. Several interviewees suggested that the cartel existed at the level of rattan traders and middlemen in Java, Sulawesi or Kalimantan. We were unable to confirm these allegations. Figure 2 shows the price increase along the market chain for sega rattan, but it is not clear whether an unusual price change does indeed occur at the level of regional rattan traders. 
Table 4. Land sales by communities to coal mines in West Kutai, showing variation in land prices.

\begin{tabular}{|c|c|}
\hline Source of information & Prices for land paid by coal mines and oil palm plantations in West Kutai and remarks \\
\hline Rattan farmer & $\begin{array}{l}\text { Oil palm plantation companies buy land for IDR } 400,000 / \text { ha, with a } 20 \% \text { plasma nutfah } \\
\text { promise to the owner. One rattan farmer sold } 3 \text { ha of land to a coal company for } \\
\text { IDR } 13,500,000 \text { or } 4,500,000 / \text { ha. More recently, farmers have been paid IDR } 15,000,000 \text { - } \\
16,500,000 / \text { ha. }\end{array}$ \\
\hline Rattan trader & $\begin{array}{l}\text { Land is sold to coal mines at IDR } 10,000,000-100,000,000 / \text { ha. The land owners explore } \\
\text { the depth of coal seams or try to find out from the companies how good the coal is } \\
\text { before setting a price target for their land. }\end{array}$ \\
\hline Local government & $\begin{array}{l}\text { In } 2003-2004 \text {, land sold to coal mines for IDR } 20,000,000 / \text { ha, but more recently for } \\
\text { IDR } 3,000,000 / \text { ha through brokers. Local people would rather sell their forestland to coal } \\
\text { mines than harvest timber, because of strict illegal logging law enforcement. }\end{array}$ \\
\hline Rattan-related NGOs & $\begin{array}{l}\text { Present land prices for coalmines in West Kutai vary from IDR } 80,000,000 / \text { ha to as high as } \\
\text { IDR } 180,000,000 / \text { ha when close to coal haul roads. Another source said that a minimum } \\
\text { of IDR } 10,000,000 / \text { ha was paid. }\end{array}$ \\
\hline
\end{tabular}

\begin{tabular}{|c|c|c|}
\hline $\begin{array}{l}\text { West Kutai } \\
\text { forest } \\
\text { - Rattan } \\
\text { harvesters } \\
\text { - IDR } \\
1200- \\
1500 / \mathrm{kg} \text { for } \\
\text { wet seg }\end{array}$ & $\begin{array}{l}\text { West Kutai } \\
\text { forest village } \\
\text { - Rattan garden } \\
\text { owners } \\
\text { - IDR } 1500 / \mathrm{kg} \text { for } \\
\text { wet sega; IDR } \\
3500 / \mathrm{kg} \text { for dry } \\
\text { sega }\end{array}$ & $\begin{array}{l}\text { West Kutai } \\
\text { town } \\
\text { - Local rattan } \\
\text { traders } \\
\text { - IDR } \\
3500- \\
4500 / \mathrm{kg} \text { for } \\
\text { dry seg }\end{array}$ \\
\hline
\end{tabular}

Samarinda
- Samarinda-
based
traders
- IDR
$2500-$
$3000 / \mathrm{kg}$ for
wet seg

Cirebon
and
Surabaya
- Java-based
traders
- IDR
$6000-$
$7000 / \mathrm{kg}$ for
dry seg

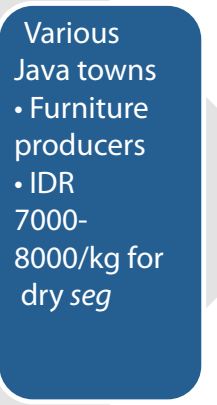

Figure 2. Prices of wet and dry sega rattan along the market chain

Finally, the interviews indicated that much of what was said about Indonesia's rattan industry and the reasons for its poor performance was informed by political opinion (as promoted by the respective industry interest groups) rather than facts. This is understandable to some extent given that there appears to be limited reliable data on trade volumes, prices or exports, let alone on illegal activities such as smuggling or falsification of documents. Without clear information about cause-effect relationships between factors, it is perhaps understandable that Indonesia's rattan policies have not led to the desired increase in economic benefits. 


\section{Analysis of rattan trade volumes and values}

Since 2000, Indonesia's rattan exports have more or less stabilized; volumes fluctuate between 140,000 and 165,000 tons with an annual Free on Board (FOB) value of between USD 300 million and USD 370 million. During this period, total exports were lower in 2005 and 2006, possibly because of the export restrictions imposed on raw and semi-processed rattan in 2005 (Figure 3).

The economic crisis that started in 2009 caused a decrease in total rattan exports from Indonesia; combined export of unprocessed rattan and rattan products dropped to just over 135,000 tons/ year (Figure 4). Rattan is considered a durable and nonessential product and hence is sold on perceived rather than actual value. Consequently, demand is strongly affected by economic fluctuations; an economic downturn will substantially influence demand, and purchases will be delayed (Tambunan 2009).
Since the export quotas were established in 2005, reported exports of semi and unprocessed rattan from Indonesia initially declined from nearly 35,000 tons in 2004 to about 18,000 tons in 2005. The impact of the export restrictions was therefore obvious. From its low in 2005, exports of unprocessed rattan increased again and stabilized at around 28,000 tons per year (Figure 4). According to data from BPS, the bulk of this amount goes to China, which in 2009 imported 24,379 tons of unprocessed rattan from Indonesia. Singapore is the second biggest importer (2,671 tons imported in 2009) and Hong Kong the third (1,103 tons imported in 2009).

Indonesia's export quota for unprocessed rattan in 2009 was 25,000 tons of raw sega and irit rattan, 16,000 tons of semi-processed sega and irit rattan, and 36,000 tons of semi-processed rattan other than sega and irit species (see Peraturan Minister

\section{Total rattan exports}

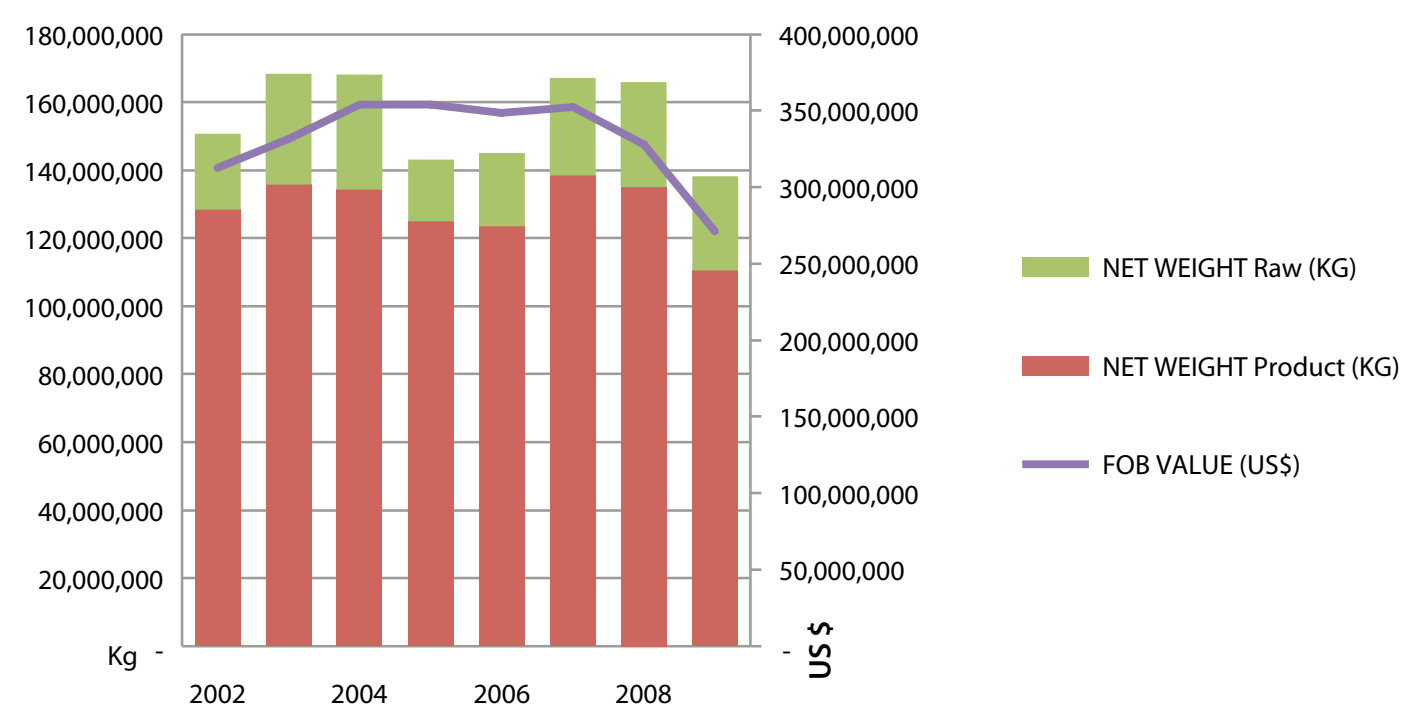

Figure 3. Total rattan exports from Indonesia (2002-2009)

Note: The left $y$-axis shows total export volumes and the right $y$-axis shows total export values (FOB) for rattan products and semi and unprocessed rattan (based on BPS data). 
Exports of semi and unprocessed rattan 2002-2009

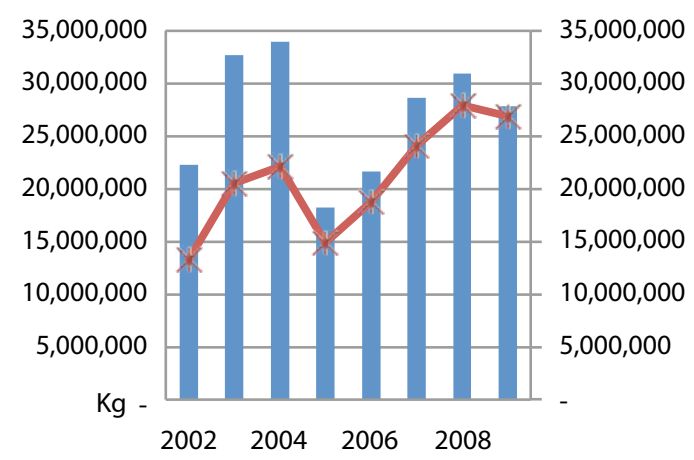

Net Weight $(\mathrm{kg})$

FOB Value (US\$)

Figure 4. Trends in export value and volume of semi and unprocessed rattan between 2002 and 2009

Note: The left $y$-axis indicates total export volumes and the right $y$-axis indicates total export values (FOB) for rattan products and semi and unprocessed rattan (based on BPS data).

of Trade and Industries Regulation Number 33/M-DAG/PER/7/2009). According to these published data, Indonesia stays well within its allotted export quotas, which total 77,000 tons, assuming that all exports are reported. Information from interviewees during the present impact assessment, however, suggests that unknown, but possibly large, amounts of rattan are smuggled out of Indonesia. As we cannot quantify the amount being smuggled, we cannot provide reliable figures on total rattan exports from the country.

Why would Indonesian rattan traders not officially trade up to the maximum allowed export quotas?

Some possible explanations are as follows:

- International demand for raw and semiprocessed rattan is too low.

- Domestic prices are higher than international prices.

- Exporting is difficult and expensive because of paperwork requirements, taxes and tariffs.

- Exporting rattan illegally is easier and cheaper than legal exporting.

An often-heard complaint from rattan traders and farmers is that the rattan export policies are too restrictive and that allowing more exports would lead to an increase in export volumes and higher rattan prices. The fact that quotas for raw and semi-processed rattan were not filled, however, suggests that these are not necessarily the main restrictions. The unfilled export quotas may also be explained by the onerous bureaucratic requirements for obtaining a rattan export permit. One trader reported working on the permit for over a year, having already paid IDR 20 million in fees but without having secured the export license. Furthermore, the rule that raw and semi-processed rattan can only be exported from certain harbors limits export opportunities. For example, Tarakan or Berau in East Kalimantan had traditional trading routes to Tawau in Malaysia, but as the two ports are not listed as legal export harbors, these international trade routes no longer exist, at least not officially. This background and additional information from interviews suggest that raw and semi-processed rattan exports are controlled by a small number of companies that have obtained rattan export licenses. These companies may regulate the export of raw and semi-processed rattan and determine whether it is more profitable to supply the domestic rattan industry (e.g. furniture makers), or legally export rattan, with the third unknown option being to export rattan illegally.

A review of trade data strongly suggests that at least some unrecorded trading is occurring. For example, according to the UN Comtrade database, in 2009 China imported 29,715 tons of rattan, most of which came from Indonesia (24,379 tons; see above). In the same year, however, China 
exported 271,532 tons of rattan products. ${ }^{1}$ Considering that China produces almost no raw rattan itself, the discrepancy between import and export data suggests that significant volumes of raw rattan trade are not reported. There are three caveats to this assumption. First, China may maintain rattan stockpiles and thus their export volumes in 2009 could be much higher than their imports if rattan was imported in previous years. We do not think this is likely considering that the rattan held in such stocks would decline in quality. A second possibility is that much of China's exported rattan products are made from polyethylene or polypropylene rattan, but this is reported as natural rattan. Third, the reported export weight of rattan furniture may also include the weight of other materials such as wood and metals used in the furniture.

Even if an export/import discrepancy is found in China, it does not necessarily mean that the unrecorded trade originates from Indonesia. For example, Vietnam and Papua New Guinea are also major exporters. However, considering Indonesia's prominence in the international rattan market and its rattan trade relationship with China (Figure 5), it is likely that at least some unreported exports would have originated in Indonesia.

Interviews with rattan furniture makers indicated that in 2010 they paid about USD 0.80 per $\mathrm{kg}$ of raw sega rattan. Quoted FOB export prices vary between USD 0.9 and 1.7 (Table 5), which is in line with the price range of USD 0.8-1.4 reported elsewhere (Jakarta Globe 2009), and also in line with information from our interviews with rattan traders, who reported export prices between USD 0.92 and USD 1.74. Considering that there are likely to be additional export costs (taxes, tariffs, administration, transportation), it appears that gross export prices are about the same as what traders would receive if they sold domestically.

We also assessed rattan product prices in Indonesia and China by looking at FOB retail prices of similar products, in this case simple rattan chairs. Prices in China appeared to be higher (average price per chair $=$ USD 39.4; SD = 26.3; $\mathrm{n}=17$ ) than in Indonesia (average price per chair = USD 26.3; SD = 7.3; $\mathrm{n}=20$ ), but the products are somewhat different. Indonesian chairs were mostly made of natural rattan and

\section{Indonesia's 4 main export destinations for rattan}

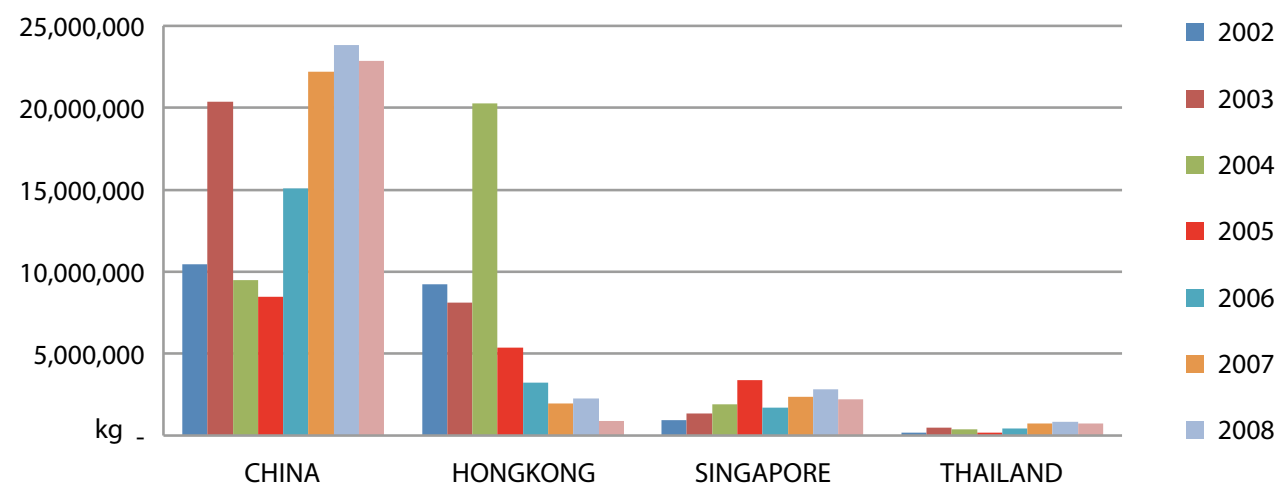

Figure 5. Indonesia's official trade partners for raw and semi-processed rattan

Source: Based on BPS data

1 It is interesting to note that these trade figures suggest that the public perception that Indonesia dominates the global rattan market with some $80 \%$ of total exports originating there (Jakarta Globe 2009; Hirschberger 2011) is no longer valid; rather, this role has been taken over by China, which exported - at least according to official data — twice as much rattan and rattan products as Indonesia in 2009. 
Table 5. Quoted export prices of raw rattan from Indonesia.

\begin{tabular}{|c|c|c|c|c|}
\hline Company name & Warehouse location & Rattan type & FOB price & Supply ability \\
\hline Future Trade Co. & $\begin{array}{l}\text { West and Central } \\
\text { Kalimantan }\end{array}$ & $\begin{array}{l}\text { Koobo Loonty with } \\
12 \mathrm{~mm} \text { and up }\end{array}$ & USD $1.2-1.7 / \mathrm{kg}$ & 90 tons per month \\
\hline $\begin{array}{l}\text { Tri Megah Sarana } \\
\text { Mandiri }\end{array}$ & $\begin{array}{l}\text { Banjarmasin, South } \\
\text { Kalimantan }\end{array}$ & $\begin{array}{l}\text { Raw rattan from } \\
\text { Kalimantan }\end{array}$ & USD $1.15-3.00 / \mathrm{kg}$ & 100 tons per month \\
\hline PT Borneo Atlantic & $\begin{array}{l}\text { Pontianak, West } \\
\text { Borneo }\end{array}$ & Sega rattan & USD $1.2-1.4 / \mathrm{kg}$ & \\
\hline $\begin{array}{l}\text { PT Arthajasa Prima } \\
\text { Sentosa }\end{array}$ & & $\begin{array}{l}\text { Planted sega rattan } \\
\text { size } 8 / 11\end{array}$ & USD 0.9-1.1/kg & 300 tons per month \\
\hline $\begin{array}{l}\text { Kaiu Trading } \\
\text { Yogyakarta }\end{array}$ & $\begin{array}{l}\text { Tanjung Perak } \\
\text { (Surabaya) }\end{array}$ & $\begin{array}{l}3 \mathrm{~mm} \text { up to } 25 \mathrm{~mm} \\
\text { (sega or other types) }\end{array}$ & USD 2/kg & 500 tons per month \\
\hline
\end{tabular}

Source: http://www.alibaba.com/showroom/raw-rattan.html

natural wood (teak or mahogany), whereas Chinese chairs mostly used synthetic rattan with aluminum frames. The difference is not absolute, and Indonesia sells more modern furniture types as well. Nevertheless, low quality and styles that no longer appeal to buyers may also be reasons why Indonesia's furniture industry appears to be losing its competitive edge. 


\section{A macroeconomic review of the rattan industry}

As mentioned elsewhere in this report, current farm-gate prices for rattan are lower than historical levels, when expressed in USD value (Figure 6). From a high of USD $0.69 / \mathrm{kg}$ in the early $1980 \mathrm{~s}$, rattan prices fell to a low of USD $0.06 / \mathrm{kg}$ in 1998 , after which they slowly increased to USD $0.15 / \mathrm{kg}$ in 2010. The relative value of rattan to farmers also fell, as a comparison with the price of rice, a major staple, makes clear (Figure 7). Data from 1844 (Schwaner 1853-1854) shows that $1 \mathrm{~kg}$ of rattan once bought as much as $15 \mathrm{~kg}$ of rice. By the early 1980s, rice and rattan prices were nearly the same. Presently, however, about $4 \mathrm{~kg}$ of rattan is required to buy $1 \mathrm{~kg}$ of rice, i.e., a 60 -fold relative devaluation of rattan versus rice over 167 years.

What are the key factors determining prices and trade volumes of Indonesian rattan? Mudhi (2008) suggests a variety of factors that might have influenced the rattan trade; these include not only export bans and quotas, but also macroeconomic factors such as currency exchange rates and Indonesia's GDP. We tested different bivariate relationships to assess the factors that appeared to influence rattan prices at the farm gate, exports of rattan products and exports of unprocessed and semi-processed rattan. Many of the people we interviewed during this assessment considered export quotas and bans to be the main factors influencing trade volumes and prices. The assumption prevalent in the furniture industry and among rattan traders is that export quotas or free rattan exports would direct trade toward overseas competitors and thus have a negative impact on Indonesia's furniture producers and exporters. This view is not supported by our data: officially reported exports of rattan products were significantly lower during years of export bans than during years of free trade and export quotas (ANOVA, $\mathrm{p}<0.0001$; Figure 8).

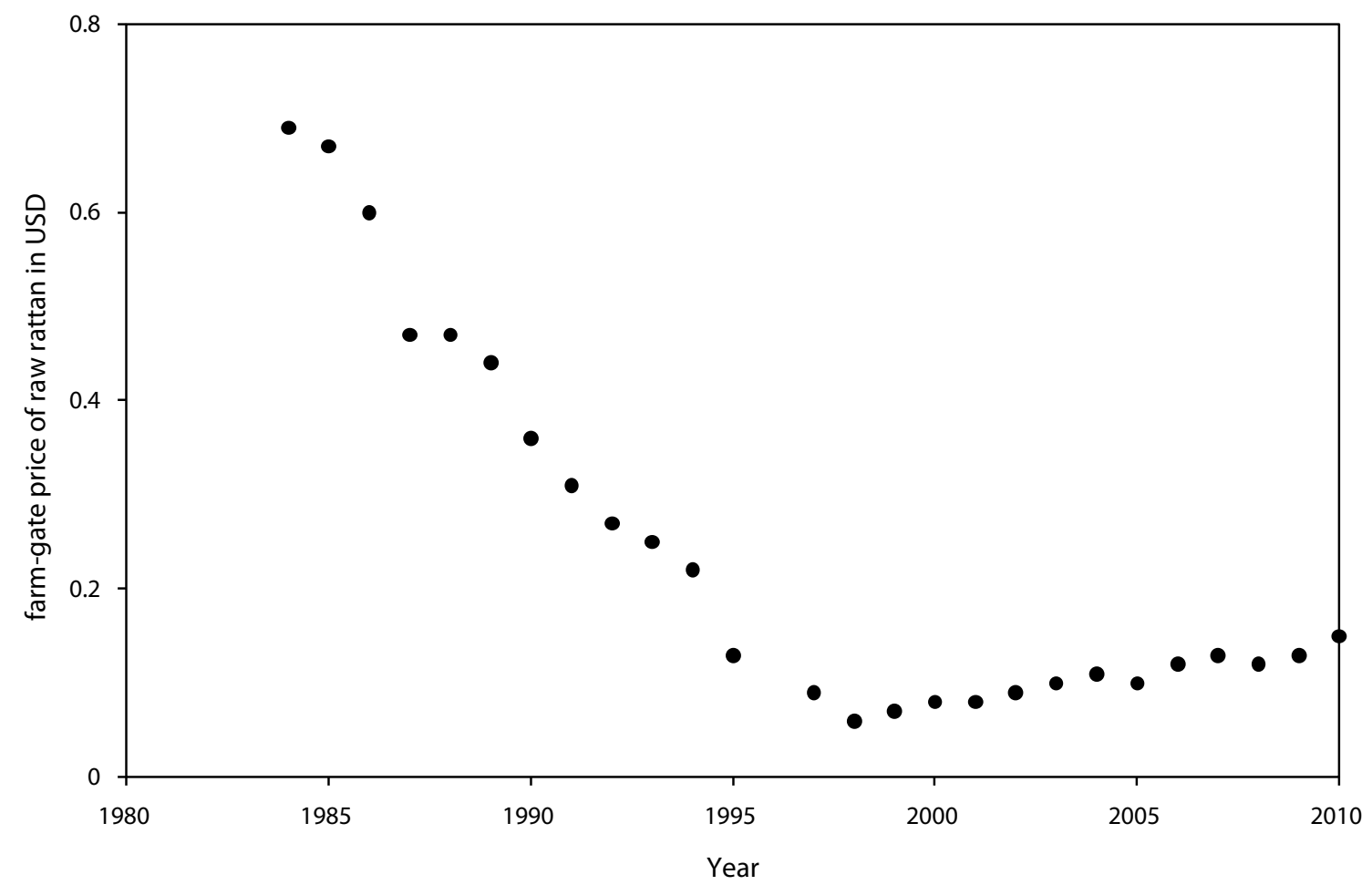

Figure 6. Farm-gate prices of rattan in West Kutai in USD at average exchange rates for each year. 


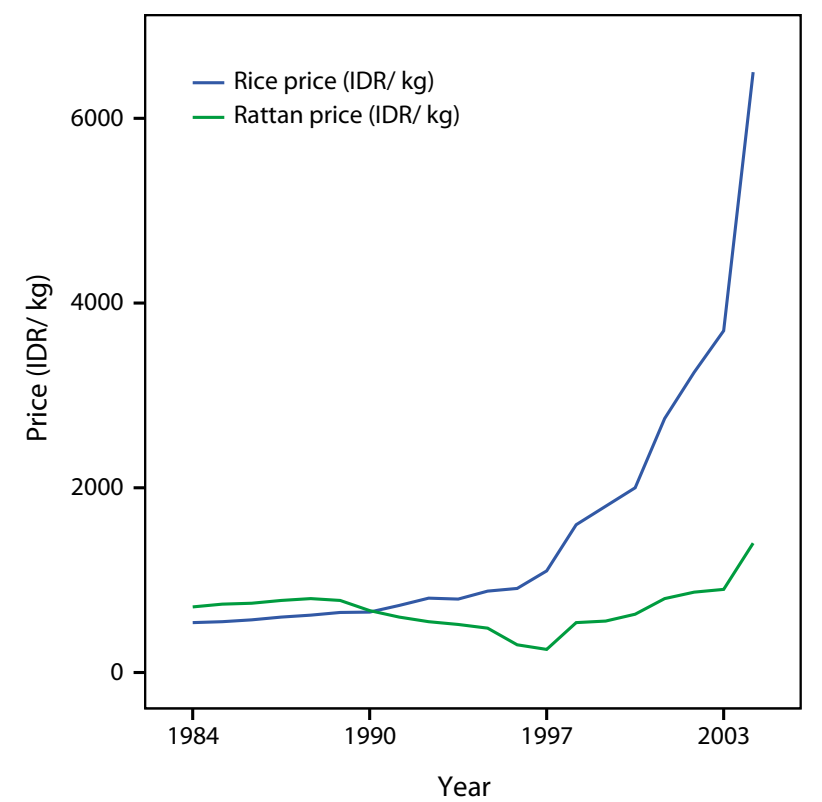

Figure 7. Prices of unprocessed rattan and rice in West Kutai from 1984 to 2010 (in IDR).

Nor was there any clear indication that, during years of free trade or partial bans, overall trade in rattan decreased (in fact, the opposite seems to be the case) or that overall trade increased significantly during periods when export of unprocessed and semi-processed rattan was banned (Figure 9). What is clear, however, is that a ban on exports of unprocessed and semi-processed rattan leads to a significant decline in their export volumes, at least for exports that were officially registered (Figure 10). This is of course to be expected, because any illegal exports would be easily recognized as such.

The major decline in rattan furniture exports, as reported by Java-based furniture producers and traders, can probably only partly be blamed on the rattan export quotas that have been in place since 2005. As seen in Figure 11, 2004, the year of the total ban, was the best year for exports of rattan furniture in the Cirebon district. The period leading up to 2004, however, was a time of free trade (under the IMF bailout agreement), and exports showed a steady increase from 10,345 containers per year in 1999 to 13,234 in 2003. Trade then declined during the period 2005-2007 when a partial ban and export quotas were in place, but then increased again under the same policy conditions in 2008, before significantly decreasing in 2009 (Figure 11). Given that policies did not

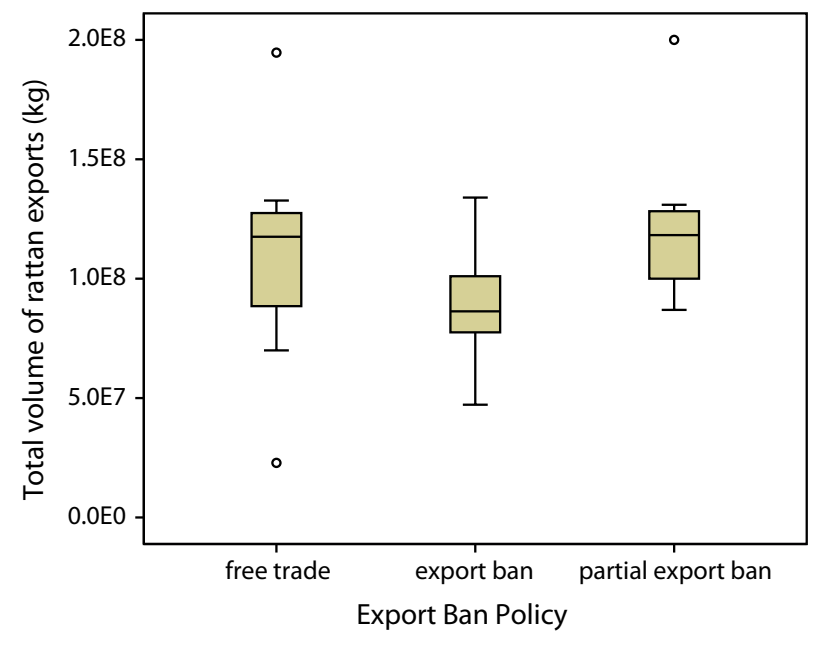

Figure 8. Export volumes of rattan products in relation to export policy in Indonesia

change during this period, this decline in 2009 is more likely the result of decreased international demand following the economic crisis, although we cannot exclude the possibility that large volumes of rattan were smuggled overseas under the partial ban conditions, thus affecting trade conditions in Java.

The impact of export policies on rattan prices could be interpreted in two ways. Figure 12 seems to generally confirm that during periods of export bans, rattan prices are higher in USD value, thus providing more purchasing power. When expressed in IDR, however, export policy does not seem to have a clear effect on price. The graphs indicate that during periods of free trade, farm-gate prices for rattan increased (both in USD - although only marginally — and in IDR), while during export bans, prices either were relatively stable (in IDR) or declined significantly (in USD). The partial export ban conditions provided a mixed picture of declining prices (in both USD and IDR) during the period 1992-1997 (when export tariffs were very high), while they increased in IDR value and stayed stable in USD value from 2005 onward.

We tested the assumption by Agus (2001) that, in addition to bans, the exchange rates for the rupiah to the yen, yuan and US dollar and Indonesian interest rates were important factors for the rattan 


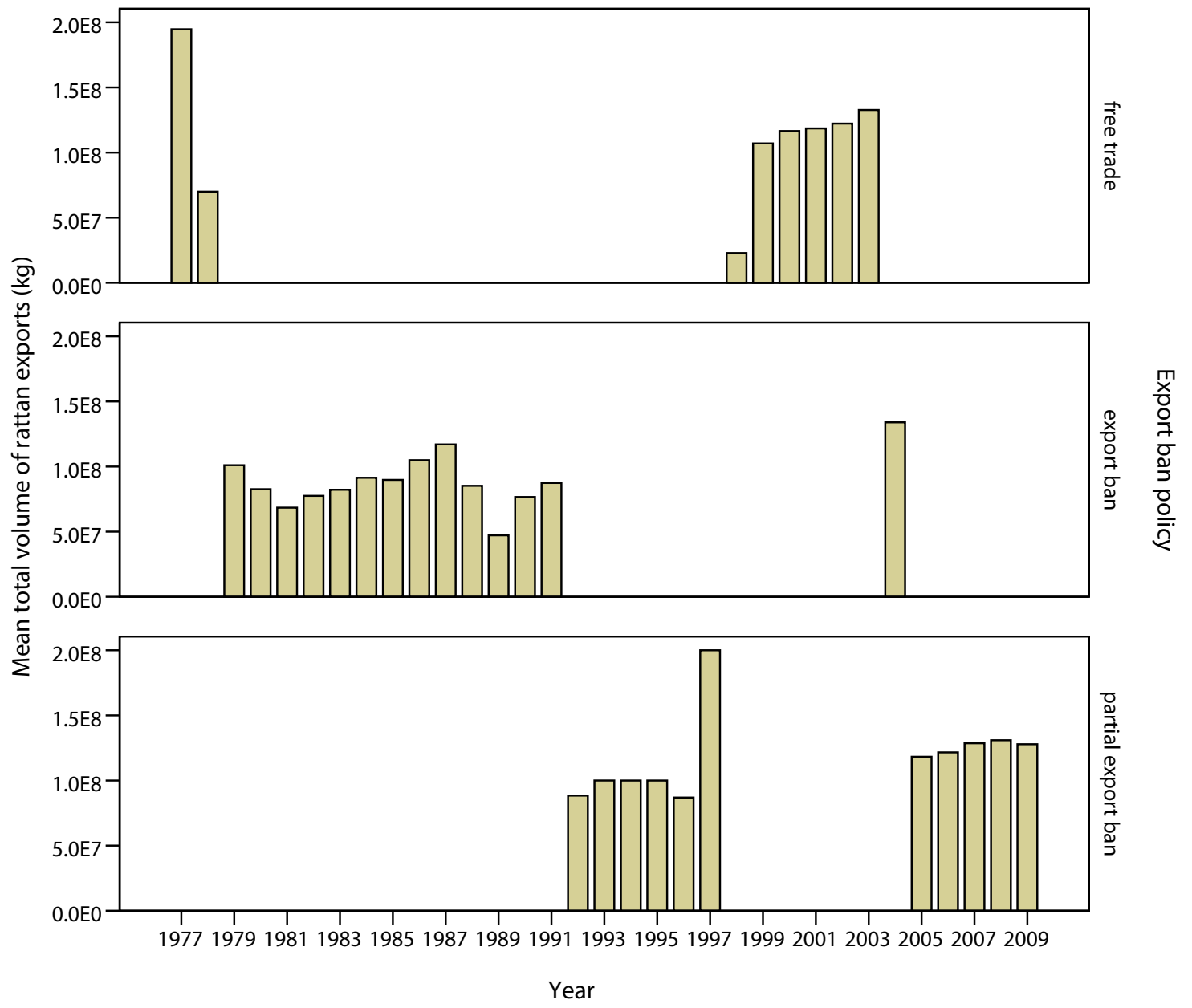

Figure 9. Total rattan exports from year to year in periods of total export bans of unprocessed and semiprocessed rattan, partial bans or free trade

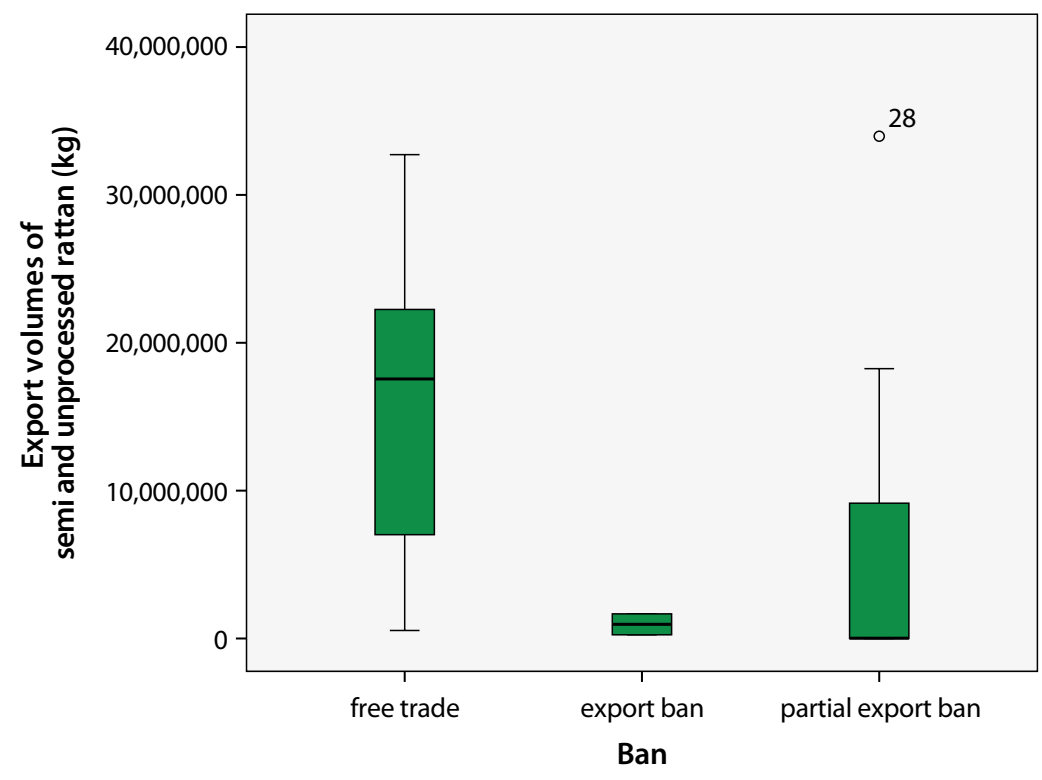

Figure 10. Export volumes of semi and unprocessed rattan under different export policies 


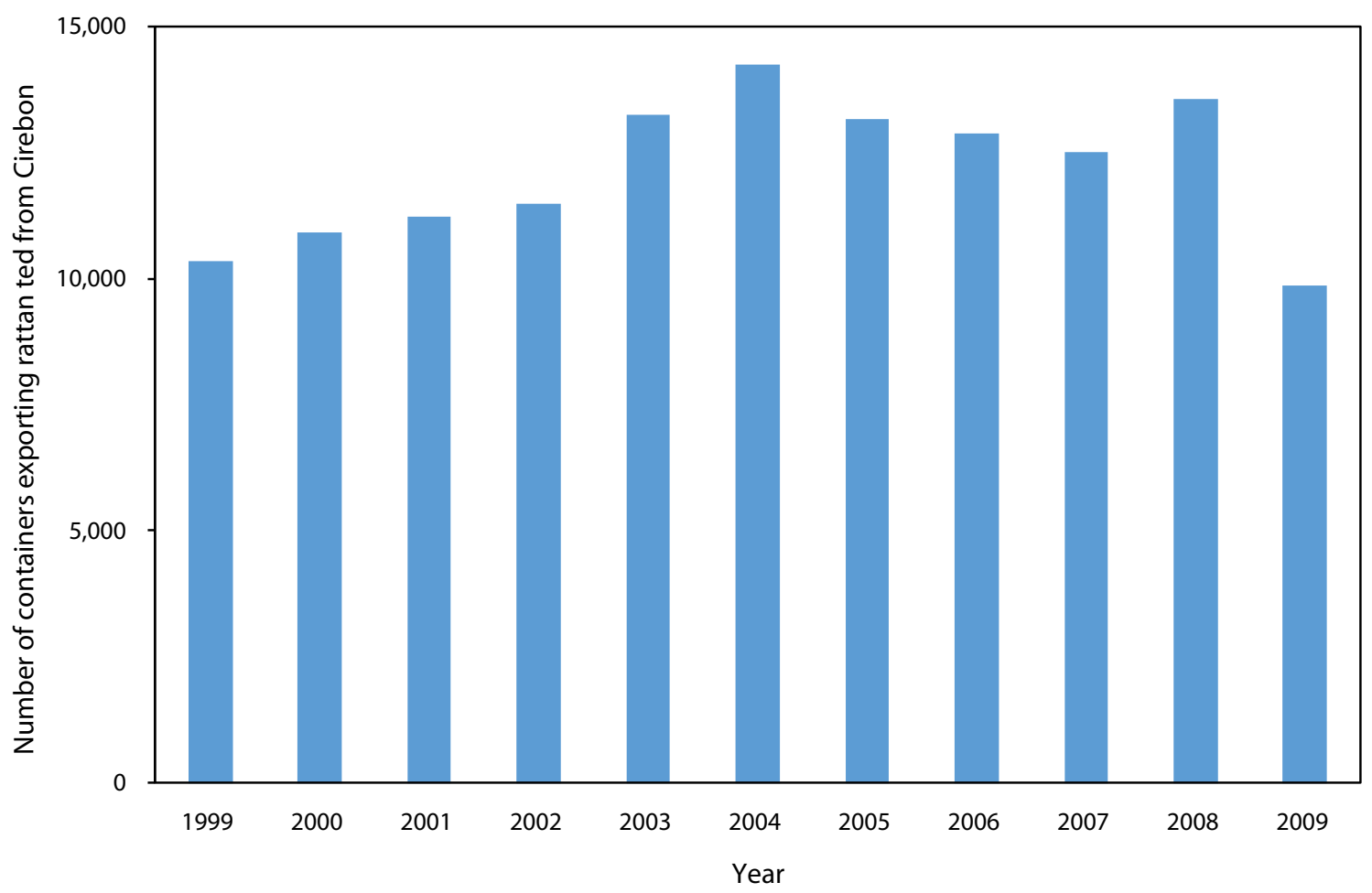

Figure 11. Export of rattan furniture from Cirebon

Source: Based on information from Disperindag Cirebon

trade and export. The IDR/USD exchange rate is indeed strongly correlated with total export volumes of rattan products (Pearson's correlation, 2-tailed: $\mathrm{r}=0.68 ; \mathrm{p}<0.0001 ; \mathrm{N}=33$ ), suggesting that the stronger the rupiah relative to the USD, the more expensive Indonesian rattan becomes and the less is exported. Neither the yen nor the yuan exchange rates showed significant correlations with Indonesian export volumes. The credit interest rates in Indonesia did, however, show significant negative correlations with total export volumes of rattan products (Pearson's correlation, 2-tailed: $r=-0.54 ; p<0.008 ; N=23$ ) (Figure 13), possibly because lower credit rates stimulate business in general.

Finally, we performed time series and regression analyses to determine the overall impact of the different macroeconomic variables on rattan farmgate prices. Our null hypothesis was that the raw rattan price corrected for inflation is influenced by the rattan product export volume from Cirebon (the Indonesian center of rattan furniture and handicraft production), the implementation of a free trade policy (in 2004) and the exchange rate of IDR to USD. By applying a linear regression, we found that the coefficient determination of the model is high at $95.5 \%$, suggesting that the model can strongly explain the variation in the rattan price corrected by inflation. The data suggest that if a free trade policy is implemented, export volumes from Cirebon increase and the rupiah weakens against the US dollar, then rattan farmgate prices (corrected by inflation) will increase. An ANOVA test showed that the model is statistically significant ( $p=0.016, \mathrm{~N}=7$ ). The model for this is: Rattan price corrected by inflation $=\mathrm{f}$ (Rattan Exported from Cirebon in Container, Rattan Free Trade Policy, IDR relative to USD), with the coefficients given in Table 6 . This indicates that trade policy is the weakest predictor of rattan farm-gate prices. Individual correlation coefficients between the variables are shown in Table 7. 

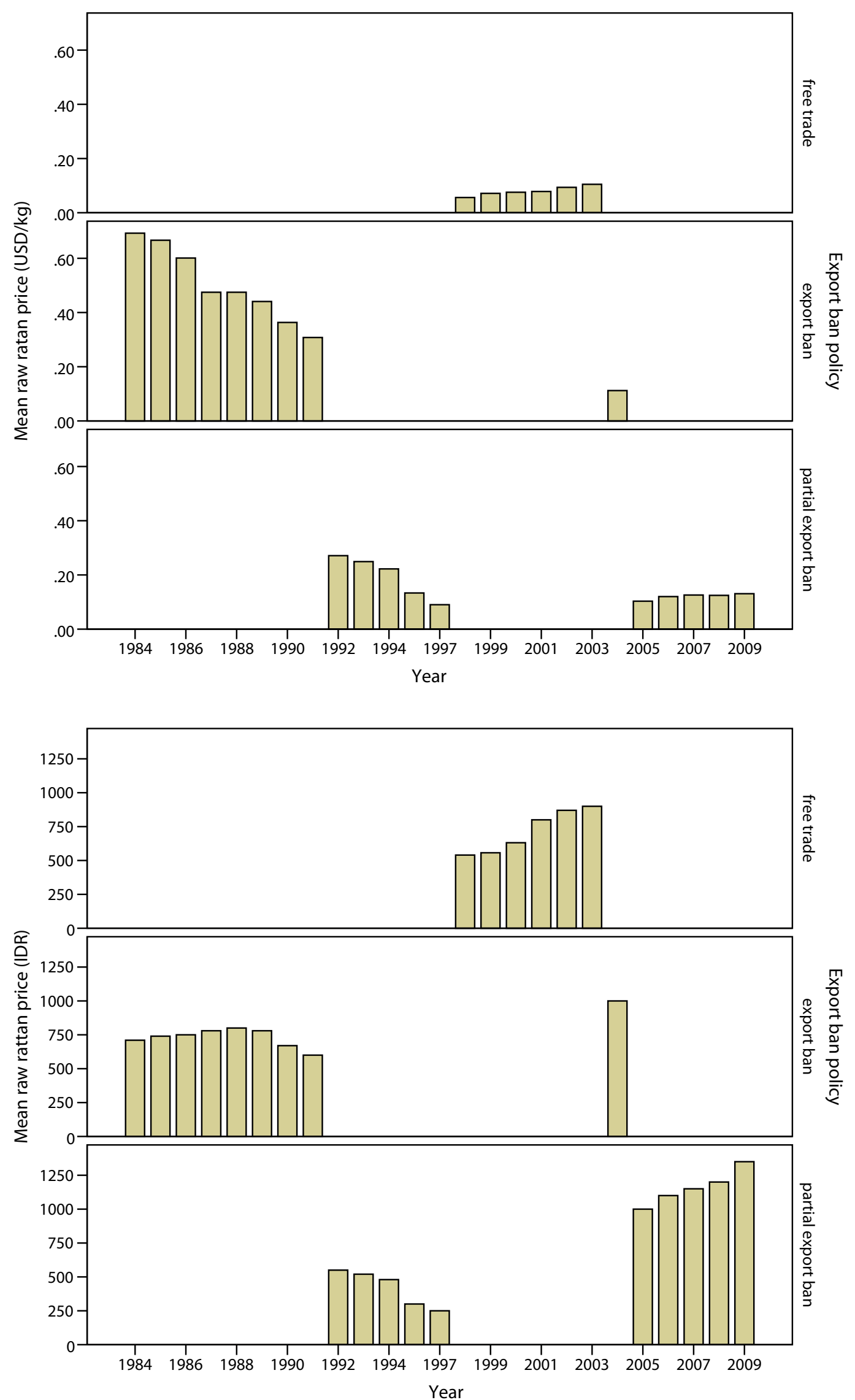

Figure 12. Rattan farm-gate prices under different trade policy conditions (a) in USD; and (b) in IDR 


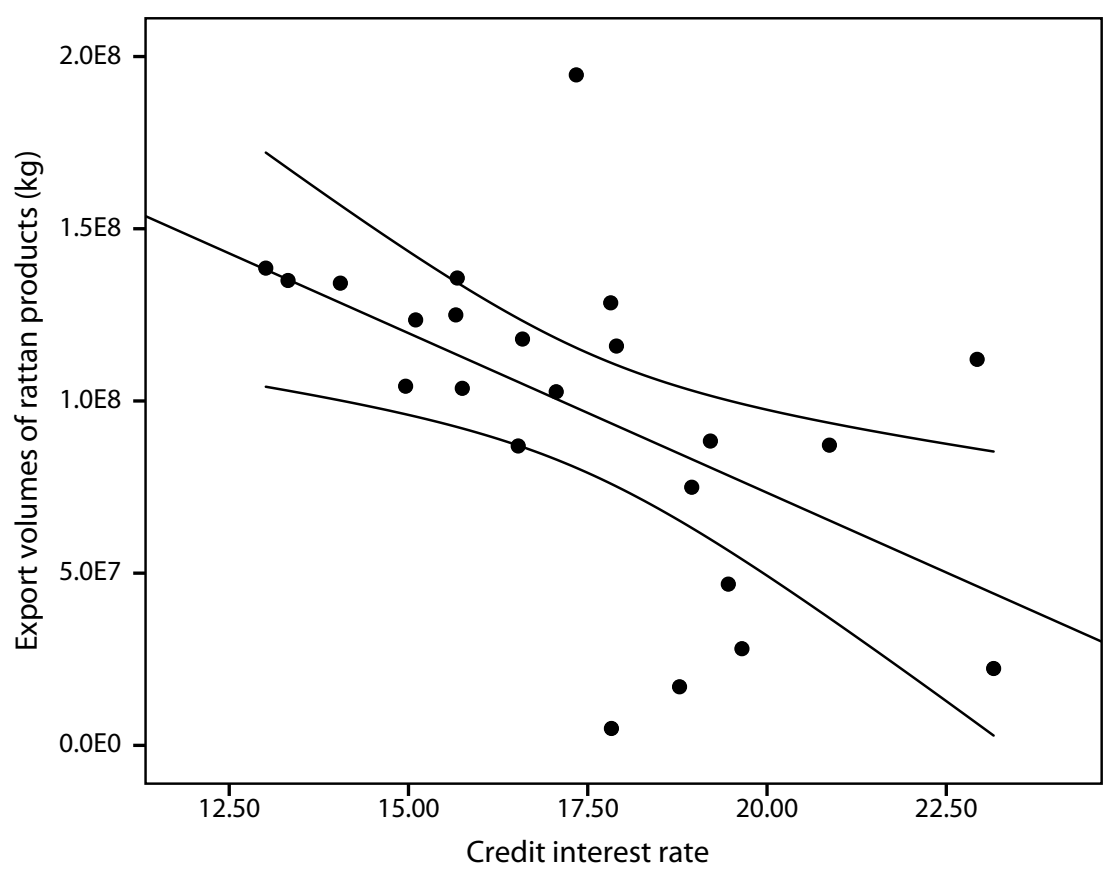

Figure 13. Indonesian credit interest rates versus total export volumes of rattan products (with $95 \%$ confidence interval around linear fit)

Table 6. Model coefficients with dependent variable: Rattan price corrected by inflation.

\begin{tabular}{|c|c|c|c|c|c|}
\hline \multirow[t]{2}{*}{ Model } & \multicolumn{2}{|c|}{ Unstandardized coefficients } & \multirow{2}{*}{$\begin{array}{c}\text { Standardized } \\
\text { coefficients }\end{array}$} & \multirow[t]{2}{*}{$\mathbf{T}$} & \multirow{2}{*}{ Sig. } \\
\hline & B & Std. Error & & & \\
\hline (Constant) & -2.547 & 0.923 & & -2.759 & 0.070 \\
\hline $\begin{array}{l}\text { Rattan Exported from } \\
\text { Cirebon (Container) }\end{array}$ & 0.000 & 0.000 & 0.857 & 4.546 & 0.020 \\
\hline Rattan Free Trade Policy & 0.118 & 0.161 & 0.140 & 0.736 & 0.515 \\
\hline IDR relative to USD & 0.000 & 0.000 & 0.470 & 3.680 & 0.035 \\
\hline
\end{tabular}

Table 7. Correlation coefficients between the variables used in the model to predict rattan farm-gate prices.

\begin{tabular}{llcccc}
\hline & & Rattan price & $\begin{array}{l}\text { Rattan export } \\
\text { from Cirebon }\end{array}$ & $\begin{array}{l}\text { Rattan free } \\
\text { trade policy }\end{array}$ & \multicolumn{2}{l}{$\begin{array}{l}\text { IDR exchange } \\
\text { rate }\end{array}$} \\
\hline Pearson's & Rattan Price & 1.000 & 0.867 & -0.641 & 0.642 \\
Correlation $^{\mathrm{a}}$ & Rattan Exported from Cirebon & 0.867 & 1.000 & -0.759 & 0.246 \\
& Rattan Free Trade Policy & -0.641 & -0.759 & 1.000 & -0.278 \\
& IDR Exchange Rate & 0.642 & 0.246 & -0.278 & 1.000 \\
Sig. (1-tailed) & Rattan Price & & 0.006 & 0.060 & 0.060 \\
& Rattan Exported from Cirebon & 0.006 & & 0.024 & 0.297 \\
& Rattan Free Trade Policy & 0.060 & 0.024 & & 0.273 \\
& IDR Exchange Rate & 0.060 & 0.297 & 0.273 & \\
\hline
\end{tabular}

a The relationship between Rattan Free Trade Policy $(0=$ no free trade and $1=$ free trade $)$ and other variables are expressed as a nonparametric relationship, others as a Pearson's correlation. 


\section{Results from repeat interviews}

\subsection{Data quality}

The CSF repeat household surveys resulted in 129 interviews. We rejected 15 of these because the households had not been surveyed in 2004 but were new additions. The quality control by one of us (MW) suggested that the interviews had not been done as carefully and accurately as we had hoped. For example, it was found that the purpose of the interview had not been clearly explained, and overall the interviews were done rather quickly (taking about 30 minutes per interview). It appeared that sometimes the interviewer had used his own judgment on what to ask rather than following the interview questionnaire. This may have resulted in misinformation or missed information, which was evident in one control interview in which a household that had that week been interviewed by CSF was asked questions again. In one instance, it turned out that the CSF interviewer had missed some income items (in this case from candlenut; in another, the income from fruit trees had been overlooked). In response, the CSF interviewer said that asking detailed questions would have been too time consuming considering the target of completing at least 125 interviews in some 20 villages.

These cross-checks thus showed that the results from the repeat interviews may not be $100 \%$ accurate or complete. This may also be the case for the initial interviews in 2004, which were likewise conducted by CSF, and in one case by the same interviewer. In fact, a CSF progress report from 1999 suggested that similar problems had occurred in the determination of household incomes (CSF 1999), although we do not know whether these problems were solved during the 2004 surveys. We compensated for the anticipated inaccuracies by analyzing only subsets of the data where we had confidence that these were accurate, for example where they concerned simple yes/no answers or where consistency checking of the data indicated that those particular questions had been asked with enough attention to detail. We realize that, as with any interview-based surveys, there is error in the data (Meijaard et al. 2011), but overall we think that our approach is justified and that the results provide a good reflection of reality.

\subsection{Impacts on local livelihoods based on repeat interviews}

From the 859 households that were initially surveyed in 2005 (assessment household incomes in 2004), our repeat interviews resulted in 98 useable household interviews. A cross tabulation showed that 9 of the 43 households that did not have a rattan garden in 2004 had established one by 2010 , and that 41 of the 55 households that did have a rattan garden in 2004 had retained it. The proportion of households with a rattan garden appeared to fall slightly, from $56.1 \%$ in 2004 to $51.0 \%$ in 2010 (Table 8), but people that owned rattan gardens in 2004 were highly likely to have still had them in 2010 (Chi-square 27.76, $\mathrm{df}=1$, $p$-value $=0.000)$.

Table 8. Cross tabulation of households with and without rattan gardens in 2004 and 2010

\begin{tabular}{lrrrr}
\hline & & \multicolumn{2}{c}{$\begin{array}{c}\text { Owned rattan } \\
\text { garden in } \\
\end{array}$} & \multicolumn{2}{c}{ 2004 } & Total \\
\cline { 2 - 4 } & & \multicolumn{1}{c}{ No } & Yes & \\
\hline Owned rattan & No & 34 & 14 & 48 \\
garden in 2011 & Yes & 9 & 41 & 50 \\
\hline Total & & $\mathbf{4 3}$ & $\mathbf{5 5}$ & $\mathbf{9 8}$ \\
\hline
\end{tabular}

In contrast, the proportion of households in the sample with rubber gardens increased considerably (Table 9): from $43.8 \%$ in 2004 to $85.7 \%$ in 2010 . Obviously, high rubber prices are driving a production shift among these farming communities.

We compared total household income in 2010 with that in 2004, and found that uncorrected 
Table 9. Cross tabulation of households with and without rubber gardens in 2004 and 2010.

\begin{tabular}{|c|c|c|c|c|}
\hline & & \multicolumn{2}{|c|}{$\begin{array}{c}\text { Owned } \\
\text { rubber garden } \\
\text { in } 2004\end{array}$} & \multirow[t]{2}{*}{ Total } \\
\hline & & No & Yes & \\
\hline \multirow{2}{*}{$\begin{array}{l}\text { Owned rubber } \\
\text { garden in } 2011\end{array}$} & No & 11 & 3 & 14 \\
\hline & Yes & 44 & 40 & 84 \\
\hline Total & & 55 & 43 & 98 \\
\hline
\end{tabular}

nominal income (not taking inflation into consideration) was substantially higher in 2010 . Average monthly household income in 2004 was IDR 1,677,676 and in 2010 IDR 3,040,170. However, using a cumulative inflation correction over these six years of $65 \%$, based on annual inflation rates, real household incomes have hardly increased (2010: IDR 1,842,527).

Monthly household expenses also increased significantly between 2004 and 2010: average 2004 expenses were IDR 1,059,563; average 2010 expenses were IDR 2,219,307. This suggests that net household income (income minus expenses) for our subset of households increased from IDR 618,113/month in 2004 to IDR 820,863/ month in 2010 , an increase of $32.8 \%$ in 6 years. This is, however, about half the cumulative consumer price inflation over the same period, suggesting that real incomes have declined.

The repeat interviews showed that $8 \%$ of our respondents in 2004 earned income from rattan compared with only $3 \%$ of respondents in 2010 . This is indicative of the declining role of rattan in community livelihoods. Those who earned income from rattan in 2004 obtained an average of $44 \%$ of their monthly household income from rattan (range 11-98\%), whereas in 2010, rattan contributed $38 \%$ of the total household income of rattan-producing families (range 8-95\%). Overall, it appears that rattan is becoming less important as a source of household income in West Kutai.

We tested whether having a rattan garden had a positive influence on household income and how this had changed between 2004 and 2010. In both years, households with rattan gardens reported slightly higher average incomes than households without rattan gardens, but in neither year were these differences statistically significant (Table 10).

Table 10. Differences in income between 2004 and 2010 for households with or without rattan gardens.

\begin{tabular}{|c|c|c|c|c|c|c|c|}
\hline \multicolumn{2}{|c|}{ Own rattan garden } & \multirow{2}{*}{$\begin{array}{l}N \\
43\end{array}$} & \multirow{2}{*}{$\begin{array}{c}\text { Mean } \\
1,514,636\end{array}$} & \multirow{2}{*}{$\begin{array}{c}\text { Median } \\
1,029,167\end{array}$} & \multirow{2}{*}{$\begin{array}{c}\text { Std deviation } \\
1,678,565\end{array}$} & \multirow{2}{*}{$\begin{array}{c}\text { F-test } \\
0.81\end{array}$} & \multirow{2}{*}{$\frac{\text { p-value }}{0.37}$} \\
\hline 2004 & No & & & & & & \\
\hline & Yes & 54 & $1,807,505$ & $1,272,333$ & $1,519,390$ & & \\
\hline & Total & 97 & $1,677,677$ & $1,199,667$ & $1,590,153$ & & \\
\hline \multirow[t]{3}{*}{2010} & No & 47 & $2,887,222$ & $2,365,000$ & $2,110,581$ & 0.29 & 0.59 \\
\hline & Yes & 50 & $3,183,942$ & $1,975,000$ & $3,140,386$ & & \\
\hline & Total & 97 & $3,040,170$ & $2,300,000$ & $2,681,498$ & & \\
\hline
\end{tabular}




\section{Discussion}

\subsection{State of rattan in Indonesia}

It appears that, since the 1980s, the Indonesian rattan industry has been the playing field of several political and economic interest groups, with different groups representing different parts of the rattan market chain. Many of the opinions held by industry stakeholders are not supported by economic facts; rather, they reflect political messaging that is then repeated by the constituents of the different groups. This became clear through the interviews conducted for this study. Through our analysis of macroeconomic data, we have tried to elucidate the state of Indonesia's rattan sector and assess how this state is influenced by the actions and policies of different stakeholders. This was made harder by the relative unreliability of the available rattanrelated datasets, in which data have been poorly recorded (for example, by not using appropriate HS codes), or possibly because of illegal activities such as rattan smuggling that would go largely unrecorded. Nevertheless, a general picture emerges of where the rattan industry is as of mid2011, the key factors that influence it and the possible solutions for improving the health of the industry and ultimately reducing deforestation and rural poverty.

The rattan industry in Indonesia appears to be at a turning point, at least with regard to its role as a reliable source of income for rural communities in East Kalimantan. Kalimantan's rattan farmers have turned to other cash crops such as rubber and oil palm. This is affecting the rattan furniture industry in Java, which often has a supply shortage; interestingly, overseas buyers also mentioned supply shortages.

The Indonesian furniture industry is also affected by a general decline in international demand for natural rattan products. Since the economic crisis in 2008, overseas consumers appear to be less interested in furniture and other rattan products, while at the same time, there is a trend toward rattan-alternatives such as synthetics and Lloyd Loom. The high value of the rupiah also makes
Indonesian exports relatively expensive, especially considering the more stable and inexpensive Chinese yuan. This is affecting the furniture industry in Java. AMKRI announced in June 2009 that, because of the decline in foreign demand for Indonesian furniture, the industry had had to lay off nearly 35,000 workers in early 2009. In May 2009 , as reported in the Indonesian newspaper Kompas (Tuesday, 11 August 2009), the chair of ASMINDO, Ambar P. Tjahyono, announced that the export value of Indonesian furniture to a number of countries had declined by $30 \%$ in the second quarter 2009, compared to 2008 (Tambunan 2010).

It is unclear how the situation of reduced rattan supplies under low price conditions and reduced international demand for rattan products is going to change in the near future, especially given the recently reinstated ban on exports of raw and semiprocessed rattan. Our analysis indicates that past rattan export bans resulted in either declining or unchanged rattan farm-gate prices, while export volumes of rattan products were significantly lower during years of export bans for raw and semiprocessed rattan than during years of free trade and export quotas/partial export bans. Thus we predict that the 2011 export ban will either lower rattan farm-gate prices or keep them at the presently low levels. This would further increase the reluctance of rattan harvesters and farmers to harvest their rattan. A shortage of rattan supply to the furniture industry may further reduce Indonesia's competitiveness with other countries such as China or Vietnam.

Information from interviews suggests that the rattan prices that farmers are receiving are at least to some extent determined by price fixing, with certain individuals able to determine the volumes supplied to the domestic and international markets and the price at which that happens. Evidence for such cartels is lacking, but it provides at least one logical explanation why relative prices (expressed in USD or corrected for inflation) have remained stable or declined over the past few years despite high demand for raw and semi-processed rattan 
(both domestic and international) and reduced supplies. In an open market, the shortage of rattan supply should have led to higher prices, thus creating more incentives for harvesting. We expect that price fixing in the internal rattan trade will prevent market mechanisms from correcting farmgate prices upward when supplies dwindle. Higher international rattan prices might increase the illegal export of rattan. Without further knowledge about price fixing, we can only speculate on this, but recommend that the Indonesian government or rattan interest groups look further into price-fixing allegations.

The main factors that influence export volumes are the relative value of the rupiah, Indonesian credit interest rates and international demand for rattan products. This demand has been affected by the global economic crisis that started in 2008. In addition, competition from China and other furniture-producing countries appears to be increasing. Without looking in more detail at the Chinese and other markets, we cannot judge whether they are indeed able to produce furniture more cheaply than Indonesia can, with less government interference and lower taxes, tariffs and other regulatory costs. What seems clear is that the Indonesian rattan industry requires a more focused direction and strategy in which markets (new and old) are targeted with a specific understanding of the kinds of products that these markets require and an ability to translate understanding into diversification of the industry. Whether it is the role of the government or of rattan industry associations such as ASMINDO to more effectively promote Indonesian rattan is unclear, but most of our informants suggested that the lack of such promotion is a major weakness of the Indonesian industry that needs to be addressed to give the industry a badly needed boost.

With regard to rattan policies, the situation of partially condoned exports that existed in 2010 and 2011 appears to be the worst of three options (no ban, partial ban, full ban). Although we cannot quantify the amount of rattan smuggling that is taking place, if any, many informants suggest that this is happening, mostly because the export quotas have left a regulatory gray area that can easily be exploited by unscrupulous traders. The partial export quotas have allegedly resulted in a situation where at least some of the unprocessed and semi-processed rattan in Indonesia is illegally exported to other countries that produce rattan furniture. There are now 62 licensed rattan exporters in Indonesia (Table 11), with official

Table 11. Number of companies with a rattan export license in each province in Indonesia (note there are none in East Kalimantan).

\begin{tabular}{|c|c|c|c|c|c|c|c|}
\hline Province & ETRa & WS TSI & Semi TSI & $\begin{array}{l}\text { W/S semi } \\
\text { TSI }\end{array}$ & $\begin{array}{c}\text { Semi non } \\
\text { TSI }\end{array}$ & $\begin{array}{c}\text { Semi TSI/ } \\
\text { Non TSI }\end{array}$ & $\begin{array}{c}\text { W/S, semi } \\
\text { TSI/ semi } \\
\text { NTSI }\end{array}$ \\
\hline North Sumatra & 2 & & & & & 2 & \\
\hline West Sumatra & 3 & & & & & 3 & \\
\hline South Sumatra & 1 & & & & 1 & & \\
\hline Lampung & 1 & & & & & & 1 \\
\hline West Kalimantan & 1 & & & & & & 1 \\
\hline Cent. Kalimantan & 26 & 20 & & 5 & & & 1 \\
\hline South Kalimantan & 13 & 5 & 1 & 5 & & & 2 \\
\hline West Nusa Tenggara & 1 & & & & 1 & & \\
\hline South Sulawesi & 6 & & & & 6 & & \\
\hline Cent. Sulawesi & 5 & & & & 5 & & \\
\hline SE Sulawesi & 2 & & & & 2 & & \\
\hline Gorontalo & 1 & & & & 1 & & \\
\hline TOTAL & 62 & 25 & 1 & 10 & 16 & 5 & 5 \\
\hline
\end{tabular}

a Abbreviations: WS = Washed and Sulfurized; TSI = Taman: Sega, Irit (planted rattan species); Semi = Semi finished; and $\mathrm{ETR}=$ Registered Rattan Exporter (Exportir Terdaftar Rotan). 
trade data suggesting that these companies export less than the export quotas. Of course, if smuggling were taking place, it would not be recorded in the official data. The exporting process and related paperwork can apparently be manipulated with relative ease, with paper records rarely coinciding with actual export volumes. The difficulty is apparently that no tools are available to weigh container contents, so volumes can only be roughly estimated. In addition, several informants told us that rattan furniture was mixed with unprocessed and semi-processed rattan hidden in the back of containers. Together, the 62 licensed exporters export some 28,000 tons of unprocessed and semi-processed rattan per year. If official figures can be trusted, $97 \%$ of that (27,265 tons) goes to China (Table 12).

Our findings about Indonesia's rattan industry are reflected in a recent country analysis by the Harvard Kennedy School Indonesia Program (Ash Center 2010). This study found that a weakness of Indonesia was that it has not succeeded in linking into the Chinese supply chains, as Thailand, Malaysia and the Philippines have done. This reflects the more general "license kerajaan" analogous to the License Raj of pre-reform India (Ash Center 2010). Over-regulation protects incumbent large firms, such as the major rattan exporters and furniture producers, and penalizes startups and small companies, such as those we encountered during our survey that were trying to break the stranglehold on rattan export. The high entry price into the industry also forces thousands of small and medium-scale rattan farmers, traders, middlemen and furniture producers to remain in the informal sector. The Harvard report suggests that retreating behind tariff barriers is not a viable strategy, and that Indonesia needs to develop a better branding strategy and the means for linking its natural resource base to both a healthier domestic industry and an international market for products such as rattan. Indonesian rattan producers along the supply chain urgently need to modernize and develop products that can compete with those from overseas. Better awareness of the kinds of products overseas markets require is needed to increase exports. This in turn should fuel domestic demand for raw and semi-processed rattan. It is unclear whether that increase in demand would be sufficiently high and would come soon enough to keep farmers interested in rattan production.

Recent policy developments do not suggest that Indonesia is changing its ways yet. The government still seems to over-regulate the rattan industry. The latest rattan trade regulation (36/M-DAG/ PER/2011) supposedly supports the raw rattan export ban by giving authorities more power to control the trade. Inter-island trade will be monitored by an independent surveyor body (PT Sucofindo, of which most shares belong to the government and it is considered a State-Owned Enterprise), which is licensed by the Ministry of Trade. Both policies will, however, likely add to the already heavy bureaucracy involved in rattan trade. Despite this policy development, there might be some room for optimism. Whereas in the past the different rattan interest groups held radically different opinions regarding rattan trade restrictions in Indonesia, it seems that increasingly these groups share similar views. Both ASMINDO and AMKRI, which have traditionally opposed the export of raw and semi-processed rattan, have since 2009 , called for larger quotas of raw and semiprocessed rattan and lower administrative costs. Ambar Tjahyono, the chairman of ASMINDO, said that he had asked the government to revise the present regulation, and allow at least 30\% of Indonesia's raw rattan to be exported (Jakarta Globe 2009). It would be helpful if the different interest groups could be further brought together by sharing hard data on the relationships between policies, prices and trade volumes, so that stakeholders can jointly develop an optimal

Table 12. China's imports and exports of rattans for plaiting, rattan basketwork, bamboo and rattan furniture, rattan plaits, rattan plaited products, and bamboo and rattan chairs for 2008.

\begin{tabular}{lccc}
\hline Reporting country & Import/export & Trading partners & Quantity (metric ton) \\
\hline China & Imports from & Indonesia & 27,265 \\
China & Imports from & All World & 37,012 \\
China & Exports to & All World & 37,001 \\
\hline
\end{tabular}


strategy that maximizes the benefits for all actors along Indonesia's rattan market chain.

\subsection{Socioeconomic impacts at the village level}

The present study suggests that rattan has become less important as a source of household income than it was in 2004. Farmers are holding on to their rattan gardens only in the hope of price increases. Nominal household incomes have increased since CIFOR finished its research, although real incomes have shown only marginal, statistically nonsignificant gains. Nor are the income differences between people with and without rattan significant. Overall, it appears that, at least in West Kutai, rattan is no longer an important source of rural income, a situation that earlier CIFOR publications had foreseen (Belcher et al. 2004b; Belcher 2007; Belcher and Schreckenberg 2007). It also appears that rattan does not play a major role in poverty alleviation, although we note that rattan does provide people with a fallback resource when other sources of income fail.

\subsection{The value of rattan production for forests and forest wildlife}

One of the reasons for the widespread focus on rattan and other NTFPs is their potential contribution to the sustainable management of forests and a reduction in deforestation. As Figure 14 shows, the rattan gardens mapped in

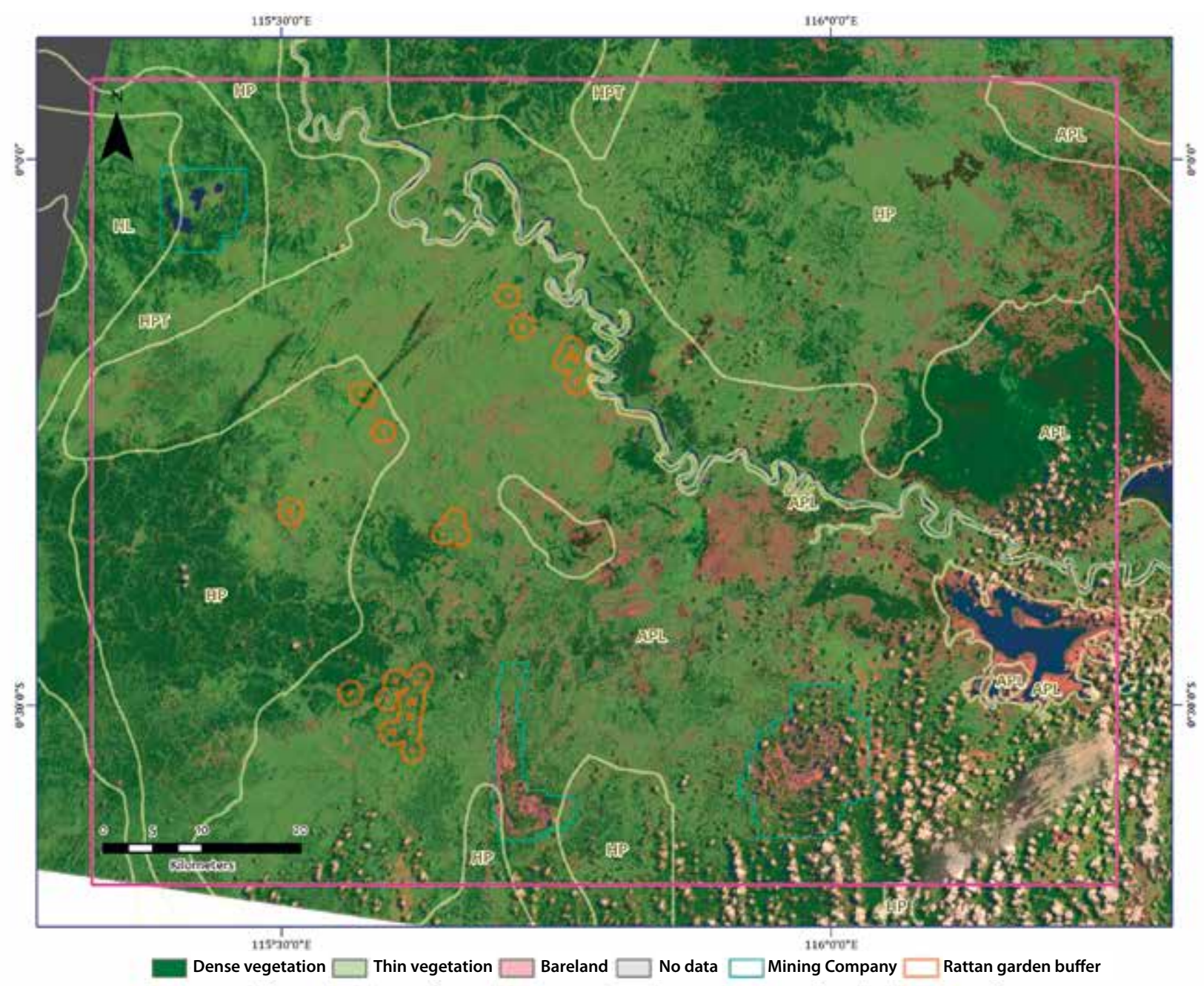

Figure 14. The $\mathbf{2 0 0 9}$ forest map for the West Kutai area, with orange polygons showing the locations of some rattan gardens mapped by SHK in 2004

Note: All mapped rattan gardens are in areas classified as 'thin vegetation'. 
2004 were in areas classified as degraded or nonforest. This is to be expected considering that rattan in West Kutai is cultivated in slash-andburn areas where forest is cleared first and then allowed to regrow. Depending on the age of the gardens, the resulting vegetation is secondary. Because rattan grows best with broad sunlight, well-maintained rattan gardens require a relatively open tree canopy. Under such conditions, rattan cultivation in West Kutai does not in itself protect forests.

In theory, it might still be possible that the revenues generated from rattan gardens inside forests would reduce incentives for local people to open these forest areas. However, the rapid economic development in West Kutai, the lack of secure tenure and the high demand for land from plantations and mining companies are providing rattan farmers with new alternatives. Among these are the option to sell land, the improved infrastructure that reduces the costs of transporting their agricultural produce, and higher prices for commodities such as rubber compared with rattan. These factors are likely to reduce any links between rattan and its role in forest protection. Nevertheless, we were unable to study this process in detail, and it is possible that rattan areas provide some buffer between more intensively used areas and remaining natural forest. In addition, the presence of rattan may make it less likely that farmers will consider selling their land or converting it to other crops as they hold on to it for potential future income. Having rattan may offer a small net benefit, although this will depend on how rattan prices develop compared with those of other commodities, as well as land prices.

The potential of rattan to play a role in biodiversity conservation has been highlighted by several authors (Matius 2004; Garcia-Fernandez and Casado 2005; Abrahamczyk et al. 2008). During the field surveys, we visited several rattan gardens in West Kutai, where most commercial rattan is planted. These gardens ranged in age from 10 to 20 years and were located in secondary forest regrowth with open canopy, an approximate tree height of 15 to $25 \mathrm{~m}$, and average dbh (diameter at breast height) of trees $(>10 \mathrm{~cm})$ of about $20-25 \mathrm{~cm}$. In general, these rattan gardens consisted of quite scrubby vegetation, and although this is based on short impressions only, these gardens appeared to be of relatively little importance to forest wildlife. Nevertheless, because rattan gardens are generally shaded and have a larger variety of plant species than monoculture plantations, rattan gardens will undoubtedly have a higher species diversity than plantations of oil palm, Eucalyptus spp. or Acacia spp. (Siebert 2002). However, there are no detailed analyses of the conservation value of rattan under different production and cultivation systems. Such studies would be important because the conservation value of an intensively managed rattan garden planted in a non-forest matrix is likely to be a lot lower than the value of an area of natural rainforest from which rattan is occasionally harvested.

Rattan may have an additional value in forest conservation and environmental services. Because many rattan species are planted close to rivers (for transportation purposes and because many species like wet conditions), such rattan gardens or stands of natural rattan could act as riverine buffers. This implies that rattan may have some impact on reducing soil runoff and erosion and play a role in flood control. This suggestion is speculative only and requires further study. 


\section{Recommendations: Suggested follow-up activities}

1. Policy discussions are hampered by a lack of information on rattan prices and trade volumes, the impact on the livelihoods of different people in the rattan industry, and the number of people whose livelihoods (partly) depend on rattan. There also remains great uncertainty about the total area of planted and natural rattan producing areas, with estimates in Indonesia varying by an order of magnitude. This uncertainty hampers the development of sustainable management strategies and annual allowable harvest volumes. ITTO (2007) has made a start at developing more accurate estimates, partly based on the production potential for different rattan species measured in the field. Nevertheless, for the total production area they still rely on poorly documented estimates from the Ministry of Forestry. A GIS-based modeling exercise should provide a step in the direction of getting better data on rattan production potential in Indonesia. There is also a need for more accurate data on actual rattan harvests, local rattan use, rattan consumption by rattan product makers, as well as reliable figures on rattan imports and exports, and a better understanding of rattan smuggling. We recommend that one person in CIFOR be assigned to maintain a database on rattan farm-gate prices and other key economic variables in Indonesia's most important rattan-producing areas: West Kutai, Central Kalimantan, Central Sulawesi, and possibly also Aceh and eastern Indonesia. This could be done on a monthly basis, mostly through email or telephone communication with CIFOR partners in these areas.

2. The Indonesian rattan industry as a whole could greatly benefit from a government roadmap that determines the available rattan supplies, the needs of the domestic industry and the potential for unprocessed and semiprocessed rattan exports. The government could also be more proactive in promoting Indonesian rattan overseas and developing new markets (Middle East, Eastern Europe, South America), reduce production costs and administrative requirements, break up possible price cartels and effectively monitor exports to reduce smuggling.

3. A possible role for CIFOR would be to provide scientific input into the development of a national rattan action plan. ITTO went some way toward this (Manila 2010), but still relied on generally poor data. More accurate information on rattan trade, future development in the rattan products market, production capacity in forests and planted rattan gardens, and international trade, including illegal trade, are all needed for betterguided rattan policies. The basic aim would be to determine what trade legislation would yield the best macro and microeconomic results for Indonesia.

4. There generally seems to be very poor information flow between rattan producers and domestic rattan consumers. It might be worth investigating whether an online trading system could be developed to enable consumers and producers to directly communicate about volumes, specifications, price and design trends. Such an investigation would also require a better understanding of the amount of price fixing that is taking place and if any effective cartels exist within the Indonesian rattan industry.

5. This study has provided a rather unsophisticated economic analysis of how different macroeconomic variables affect rattan trade volumes and prices in Indonesia. A more robust analysis of the data might provide a more convincing tool to revise rattan-related policies or provide more specific policy recommendations and discuss these with rattan interest groups. 


\section{References}

Abrahamczyk S, Kessler M, Putra DD, Waltert $\mathrm{M}$ and Tscharntke T. 2008. The value of differently managed cacao plantations for forest bird conservation in Sulawesi, Indonesia. Bird Conservation International 18:349-62.

Achdiawan R and Belcher B. 2005. CIFOR Contributions to Rattan Export Policy in Indonesia: Brief History and Lessons. Bogor, Indonesia: CIFOR.

Agus. 2001. Perdagangan Komoditi Rotan Indonesia di Pasar Domestik dan Jepang. Analisis Dampak Perubahan Faktor Ekonomi [Thesis]. Bogor, Indonesia: Institut Pertanian Bogor.

Aryasena Wicker Furniture. 2010. Member of ASMINDO. Accessed 10 January 2011. http:// www.thewickerfurniture.com/the-company/ member-of-asmindo

Ash Center. 2010. From Reformasi to Institutional Transformation: A Strategic Assessment of Indonesia's Prospects for Growth, Equity and Democratic Governance. Cambridge, Mass.: Harvard Kennedy School Indonesia Program.

[ADB] Asian Development Bank. 2009. Key Indicators for Asia and the Pacific 2009. Indonesia. Accessed 31 December 2013. http://www.adb.org/sites/default/files/ KI/2009/INO.pdf.

Belcher B. 2007. The feasibility of rattan cultivation within shifting cultivation systems: the role of policy and market institutions. In Cairns M, ed. Voices from the Forest: Integrating Indigenous Knowledge into Sustainable Upland Farming. Washington, DC: Resources For the Future. 729-42.

Belcher B. 1998. A production-to-consumption systems approach: Lessons from the bamboo and rattan sectors in Asia. In Wollenberg E and Ingles A, eds. Incomes from the Forest: Methods for the Development and Conservation of Forest Products for Local Communities. Bogor, Indonesia: CIFOR. 57-84.

Belcher B, Levang P, Dewi S, Achdiawan R, Tarigan J, Riva WF, Kurniawan I, Sitorus $S$ and Mustikasari R. 2004a. Resilience and evolution in a managed NTFP system: Evidence from the rattan gardens of
Kalimantan. Proceedings of the Workshop Cultivating (in) Tropical Forests: The Evolution and Sustainability of Systems of Management between Extractivism and Plantations, 28 June - 1 July 2000, Kraemmervika, Lofoten, Norway. Wageningen, Netherlands: European Tropical Forest Research Network (ETFRN)

Belcher B, Rujehan, Imang $\mathrm{N}$ and Achdiawan R. 2004b. Rattan, rubber, or oil palm: cultural and financial considerations for farmers in Kalimantan. Economic Botany 58:S77-S87.

Belcher B and Schreckenberg K. 2007. Commercialisation of non-timber forest products: A reality check. Development Policy Review 25:355-77.

[CSF] Center for Social Forestry. 1999. Progress Report of CSF-CIFOR Collaborative Research in the Dynamics of NTFP-based Livelihood Strategies in a Changing Socio-Economic Environment: Case [sic] from villages in Kutai and Pasir Districts, East Kalimantan. Samarinda, Indonesia: CSF Team, Mulawarman University.

de Beer JH and McDermott MJ. 1996. The Economic Value of Non-Timber Forest Products in Southeast Asia. Amsterdam: Netherlands Committee for IUCN The World Conservation Union.

de Jong W, Rohadi D, Belcher B, Mustikasari $\mathrm{R}$ and Levang P. 2003 The political ecology of forest products in Indonesia: a history of changing adversaries. In Tuk-Po, L, de Jong $\mathrm{W}$ and Abe K, eds. The Political Ecology of Forests in Southeast Asia. Kyoto, Japan: Kyoto University Press. 107-32.

Dewi S, Belcher B and Puntodewo A. 2005. Village economic opportunity, forest dependence, and rural livelihoods in East Kalimantan, Indonesia. World Development 33:1419-34.

Fried S and Rich B. 1998. NGO letter to The World Bank and International Monetary Fund referring Indonesia's Bailout. Environmental Defense Fund, Washington, D.C., March 1998. 
Garcia-Fernandez C and Casado MA. 2005. Forest recovery in managed agroforestry systems: The case of benzoin and rattan gardens in Indonesia. Forest Ecology and Management 214:158-69.

Godoy R. 1990. The economics of traditional rattan cultivation. Agroforestry Systems 12:163-72.

Godoy R and Ching Feaw T. 1989. The profitability of smallholder rattan cultivation in Southern Borneo, Indonesia. Human Ecology 17:347-63.

Godoy R and Rodrik D. 1989. The Costs and Consequences of Export Restrictions on NonTimber Tropical Forest Products: Indonesia's Export Policy on Rattan. Unpublished Manuscript. Harvard Institute for International Development, Cambridge, MA

Godoy RA and Ching Feaw T. 1991. Agricultural diversification among smallholder rattan cultivators in Central Kalimantan, Indonesia. Agroforestry Systems 13:27-40.

Gunawan. 2002. Keragaan Perdagangan Rotan dan Produksi Rotan Indonesia di Pasar Domestik dan Intemasional: Suatu Analisis Simulasi Kebijakan [Dissertation]. Bogor, Indonesia: Institut Pertanian Bogor.

Gunawan AH and Siregar RY. 2009. Survey of recent developments. Bulletin of Indonesian Economic Studies 45:9-38.

Haury D and Saragih B. 1996. Processing and Marketing of Rattan. SFMP Document No. 6a. Samarinda, Indonesia: Indonesia-Germany Development Cooperation.

Hirschberger P. 2011. Global Rattan Trade: Pressure on Forest Resources - Analysis and Challenges. Vienna: WWF Austria.

[ITTO] International Tropical Timber Organization. 2007. Technical report: Inventory of standing stocks in natural forest and plantation. Development of Sustainable Rattan Production of Rattan Smallholders and Industry in Indonesia. PD 108/01 Rev. 3(1). Jakarta: International Tropical Trade Organization.

Jakarta Globe. 17 March 2009. Rattan firms hope government will end export quotas. Jakarta Globe. Accessed 15 March 2011. http:// www.thejakartaglobe.com/justAdded/rattanfirms-hope-government-will-end-exportquotas/269704

Jakarta Post. 15 July 2010. Rattan export limitation harms local industry. Jakarta Post. Accessed 21 January 2011. http://www. thejakartapost.com/news/2010/07/15/rattanexport-limitation-harms-local-industry.html

Kandi RD. 28 February 2011. Government reduces rattan product exports. Indonesia Finance Today.

Kartodihardjo S. 1999. The State of Bamboo and Rattan Development in Indonesia. Land Rehabilitation and Social Forestry. The Ministry of Forestry and Estate Crops, Indonesia.

Kompas. 26 May 2010. Tata niaga rotan bermuatan politik. Kompas. Accessed 4 February 2011. http://www.rotanindonesia. org/index.php/kliping-berita-rotan-danproduk-rotan/792-tata-niaga-rotanbermuatan-politik-.

Manila AC. 2010. Ex-post Evaluation Report. ITTO Project PD 108/01 Rev.3 (I) Development of Sustainable Rattan Production and Utilization through Participation of Rattan Small Holders and Industry in Indonesia. Yokohama, Japan: International Tropical Trade Organization.

Marks SV. 2009. Economic policies of the Habibie presidency: A retrospective. Bulletin of Indonesian Economic Studies 45:39-60.

Matius P. 2004. Plant Diversity and Utilization of Rattan Garden. A Contribution to Participatory Biodiversity Conservation within the Benuaq and Tunjung Tribe in East Kalimantan, Indonesia. Eschborn, Germany: Deutsche Gesellschaft fuer Technische Zusammenarbeit (GTZ) GmbH.

Meijaard E, Mengersen K, Buchori D, Nurcahyo A, Ancrenaz M, Wich S, Atmoko SSU, Tjiu A, Prasetyo D, Nardiyono, Hadiprakarsa Y, Christy L, Wells J, Albar G and Marshall AJ. 2011. Why don't we ask? A complementary method for assessing the status of great apes. PloS ONE 6:e18008.

Miranda ML. 1987. Minor Forest Product Exports [Progress report]. Jakarta: Ministry of Finance of the Republic of Indonesia.

Mudhi S. 2008. Prosfek, Pemasaran dan Kebijakan Hasil Hutan Bukan Kayu Rotan [Thesis]. Departemen Ilmu Kehutanan, Fakultas Pertanian, Universitas Sumatera Utara.

PT Capricorn Indonesia Consult Inc. 1988. A Study on the Prospects on [sic] the Rattan Industry and Market. Jakarta: PT Capricorn Indonesia Consult Inc.

Pambudhi F, Belcher B, Levang P and Dewi S. 2004. Rattan (Calamus spp.) gardens of Kalimantan: Resilience and evolution in a 
managed non-timber forest product system. In Kusters K and Belcher B, eds. Forest Products, Livelihoods and Conservation: Case Studies of Non-Timber Forest Product Systems. Vol. 1 Asia. Bogor, Indonesia: CIFOR. 347-64.

Peluso NL. 1993. Networking in the commons: A tragedy for rattan? Indonesia 35:95-108.

Peluso NL. 1986. Rattan Industries in East Kalimantan, Indonesia. Paper commissioned by FAO Policy and Planning Service, Forestry Department.

Priasukama S. 1989. Rattan for economic development in East Kalimantan. In Rao AN and Vongkaluang I, eds. Recent Research on Rattan: Proceedings of the International Rattan Seminar. 12-14 November 1987, Chiang Mai, Thailand. Faculty of Forestry, Kasetsart University and IRDC Canada. 248-57.

Purnama BM, Prahast $\mathrm{H}$ and Nasendi BD. 1998. Rattan in East and South Kalimantan, Indonesia: A Case Study of the Production-toConsumption Systems. INBAR Working Paper No. 21. Bogor, Indonesia: Socio-economic Research and Development Centre.

Putra VA. 2010. Analisis pengaruh suku bunga kredit, PDB, inflasi, dan tingkat teknologi terhadap PMDN di Indonesia. Periode 19862008. [Unpublished manuscript]. Semarang, Indonesia: Faculty of Economics, Diponegoro University.

Quang VD. 2004. Domestication of rattan (Calamus tetradactylus) in the buffer zone of $\mathrm{Ke}$ Go Natural reserve Area, Cam Xuyen district, Vietnam. In Kusters K and Belcher B, eds. Forest Products, Livelihoods and Conservation: Case Studies of non-timber forest product systems. Vol. 1 - Asia. Bogor, Indonesia: CIFOR. 283-94.

Rattanland. 2011. The rattan industry at a glance. Accessed 11 January 2011. http://www. rattanland.com/rtl_product_info/76.html

Rukmana N. 9 May 2005. Cirebon rattan industry on the brink of collapse, 32,000 workers laid off. Jakarta Post.

Safran EB and Godoy RA. 1993. Effects of government policies on smallholder palm cultivation - an example from Borneo. Human Organization 52:294-98.

Sastry CB. 2001. Rattan in the twenty-first century: An overview of major issues and needs for the global development of rattan. Unasylva 205:3-12.

Schwaner CALM. 1853-1854. Borneo. Beschrijving van het stroomgebied van den Barito en reizen langs eenige voorname riveiren van het zuidoostelijke gedeelte van dat eiland in de jaren 1843-1847. 2 Vols. Amsterdam: van Kampen.

Siebert SF. 2002. From shade- to sun-grown perennial crops in Sulawesi, Indonesia: Implications for biodiversity conservation and soil fertility. Biodiversity \& Conservation 11:1889-1902.

Tambunan M. 1995. The raw rattan export bans and the impact on industrial development. Kelola 10:100-19.

Tambunan TTH. 2009. The Rise in Non-Tariff Protectionism and Recovery from the 2008/2009 Global Economic Crisis: The Indonesian Story. Presentation, Research Workshop on Rising Non-Tariff Protectionism and Crisis Recovery. Session 6: NTMs and Developing Countries. Organized in cooperation with ARTNeT, GTA, UNCTAD and WTO. Macao, China, 14-15 December.

Tambunan, TTH. 2010. Crisis-Adjustment Strategies Adopted by SMEs in Copying with the 2008-2009 Global Economic Crisis: The Case of Indonesia. Presentation, Asia-Pacific Economic Association Conference. Hong Kong, 8-9 July.

TradeData International. 2005. An Analysis of World Trade in Rattan and Products made from Rattan. November 2005. Unpublished report.

von Luebke C. 2009. Striking the Right Balance: Economic Concentration and Local Government Performance in Indonesia and the Philippines. Presentation, 2009 Annual Meeting of the American Political Science Association. Toronto, 3-6 September.

Watanabe NM and Suzuki E. 2008. Species diversity, abundance, and vertical size structure of rattans in Borneo and Java. Biodiversity \& Conservation 17:523-38.

Weinstock JA. 1983. Borneo rattan: A complement to swidden agriculture. Economic Botany $37: 1-5$.

World Bank. 2011. Data. Accessed 21-22 January 2011. http://data.worldbank.org/indicator/ NE.EXP.GNFS.ZS/countries. 


\section{Appendix: Results from in-depth interviews}

From our field visits and in-depth interviews, we developed a general understanding of the state of rattan trade in Indonesia as seen from different perspectives. The overall impression is that rattan trade in 2011 is in decline. Raw rattan prices hardly justify the effort of harvesting it and many rattan gardens are no longer maintained. While rattan supply is suppressed, demand seems to remain high, but this does not seem to be leading to higher prices. In the following, we explore various aspects of the rattan trade dynamics, using the responses from interviews.

\section{Rattan harvesters and farmers}

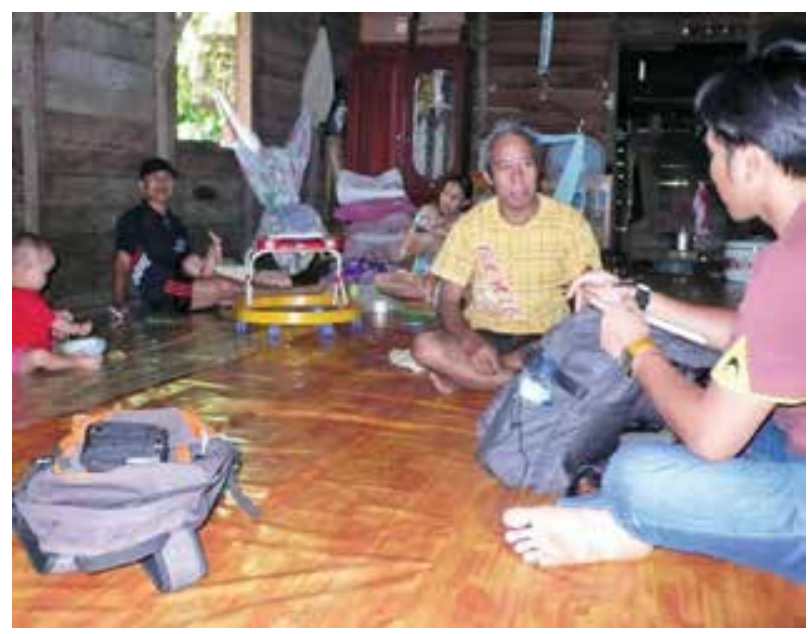

The uncompetitive price of rattan was clearly expressed by one farmer who said that, in 1985, $1 \mathrm{~kg}$ of rattan would buy $3 \mathrm{~kg}$ of rice, whereas now $4 \mathrm{~kg}$ of rattan is needed to buy $1 \mathrm{~kg}$ of rice. Rattan prices are now so low that few people are harvesting. This has been amplified by the arrival in the area of oil palm companies. Oil palm companies pay local workers IDR 46,000 per day for relatively light work. To get the same amount of money, they would have to harvest some $30 \mathrm{~kg}$ of rattan per day, which is much harder work. People are happy about the presence of oil palm plantations in this remote area, because of the income security it provides them.
There is still a lot of rattan in the area, both planted and natural, but people are neither cutting nor maintaining these rattan stands. This is also because the price of rubber, at IDR $14,000 / \mathrm{kg}$, was higher than ever and farmers could make as much as IDR 4,500,000 per month from rubber cultivation. They would have to harvest 3 tons of rattan per hectare per month to compete with rubber. In 2005, the price of dry rattan was IDR $2,800 / \mathrm{kg}$, even lower than now, but people were still harvesting rattan because the rubber and oil palm alternatives were not yet available. The farmers said they would cut rattan again if the price for wet sega rattan was between IDR 2,000 and 3,000/kg. If prices do not rise soon, they are likely to convert their land to rubber or sell it to the companies. Rubber has similar advantages as rattan: both can be harvested whenever there is a need for cash and both can be stored for some time after harvesting without loss of quality (although rubber can be stored considerably longer than rattan). Also, like rattan, rubber requires little maintenance and low levels of fertilizer (if any), especially compared with oil palm, which requires much more weeding and fertilizer, and the fruits must be harvested when ripe and processed in a factory within 24 hours of harvest.

One rattan collector commented that rattan is becoming increasingly hard to find. He used to walk about $1-2 \mathrm{~km}$ to collect rattan but nowadays he needs to carry the rattan over much longer distances. He said that the demand for rattan remained high but that prices were too low at the moment and few people bothered to look for rattan. Revenue sharing between the rattan garden owner and collectors is increasingly common, often on a 50-50 basis. One of the rattan species that is still commonly harvested is pulut merah, for which farm-gate prices of IDR $6,000 / \mathrm{kg}$ are still paid, i.e. four times as much as for sega.

Other NTFPs such as forest honey and gaharu (Aquilaria malaccensis) are rare in this area because of over-extraction. Illegal logging was once rampant but has stopped because of strict law enforcement. 
One farmer expressed the hope that these restrictions would be reduced soon, so that they could go back to cutting trees.

It is important to keep farming activities going because it strengthens tenure and it makes it harder for other people to steal the land. However, careful timing is required because the longer farmers hold onto their land, the more likely someone else will lay claim to it and sell it to a company without their knowledge. ${ }^{2}$ One farmer felt that he had to sell his land to a coalmining company, even though the price was too low, before someone else claimed the land and sold it.

One farmer said that, overall, rattan contributes very little to the household's welfare. Rather, they keep rattan because it is low maintenance and it can cover small expenses, but it does not generate enough revenue for investment and therefore does not provide a means to substantially lift people's standard of living. He concluded that the future of rattan is unclear, as there is neither direction from government nor from price.

\section{Local rattan traders}

There is still a very large amount of harvestable rattan in West Kutai. In the Besiq area alone, as one trader told us, some 100-200 tons of rattan could be harvested each year. However, very few can be bothered with rattan because of the low prices. Local traders are still buying rattan, although at a rapidly decreasing rate. One trader was still selling 30 tons of rattan per month in 2009, but that had fallen to 2.5 tons per month in 2010. The demand is there, but the supply is not. This is causing a shift in the trade away from Kalimantan to Sulawesi, where people have fewer alternative sources of income and are therefore still willing to harvest rattan.

Many farmers are selling their land to oil palm plantations, although more recently farmers are having second thoughts about this. Increasingly rattan is used in land speculation as it secures tenure, and the presence of rattan makes it less likely that the land is converted to other uses. One trader requested that CIFOR provide help in policy discussions with a view to increasing rattan prices.

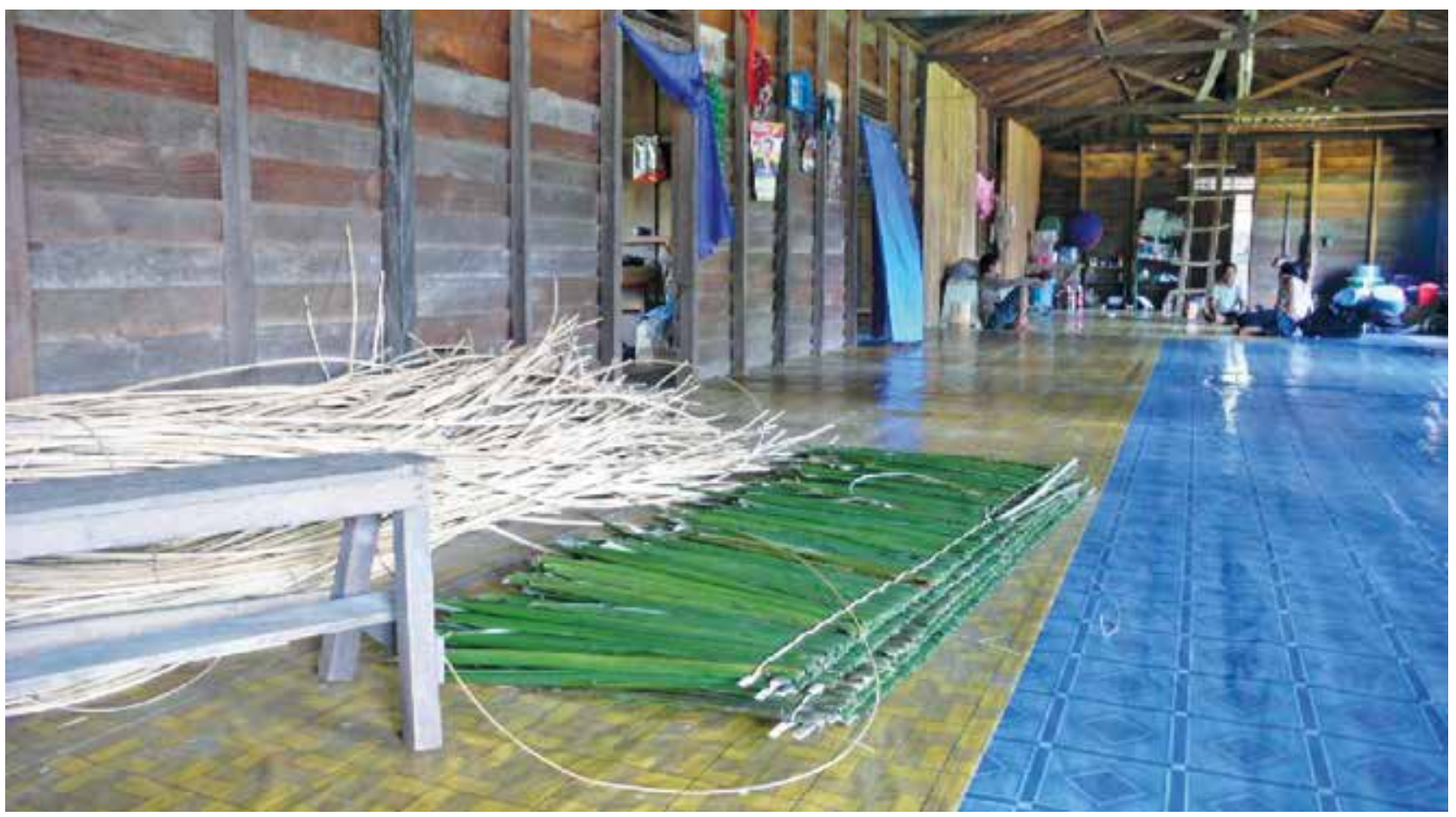

2 Farmers rarely have legal title to land and tenure rights are often claimed on the basis of present or past use. 


\section{Rattan middlemen}

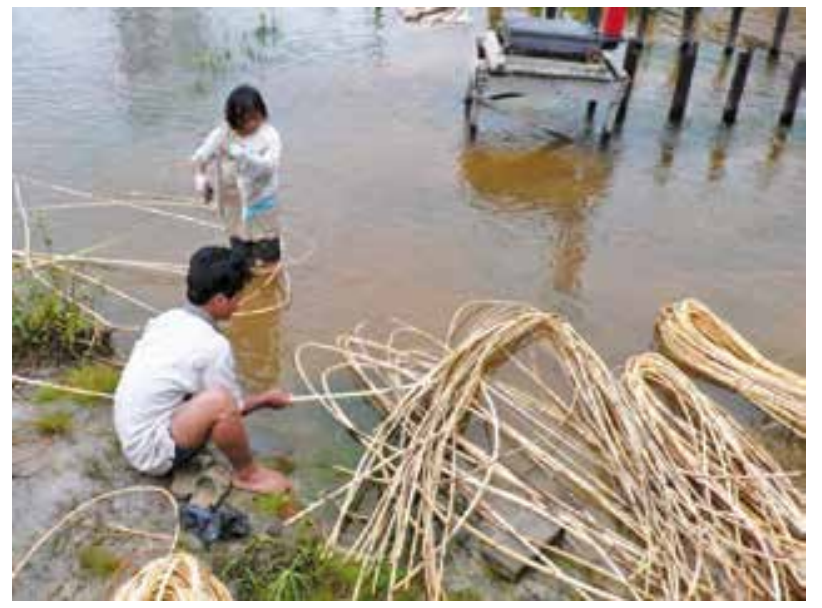

Rattan trade in West Kutai District has significantly declined. One trader reported that, in the 1980s, he would trade up to 100 tons of rattan/month, whereas now he generally trades between 2 and 3 tons/month. Another trader said, "Now the money is looking for rattan, whereas in the past rattan looked for the money." The demand from Java is strong enough and rattan is still growing in the forest and gardens, but very few are harvesting. In general, indigenous people have stopped farming and are looking at opportunities to sell their land or grow more lucrative cash crops. Only the Javanese immigrant population is still growing crops.

\section{Several traders commented on the SKAU} regulation (see Box 2), which apparently adds some $5-10 \%$ to the cost of trading. The SKAU regulation is stifling trade and adds significantly to the cost of trading rattan: "[The Ministry of] Forestry is greedy. They already eat enough from timber, why do they want to eat more from rattan, which is not even grown in forests?"

Several traders raised the issue of the lack of supply of rattan workers. Young people do not want to work in forests anymore. They want a motorbike that can take them to their rubber garden, but do not like anything requiring long walks or carrying heavy loads. This makes it hard to keep rattan production up. "Morality has changed in West Kutai with all the developments - it is all money grabbing — rattan does not fit anymore in this world."

Nevertheless, rattan traders remained optimistic. If the rattan price is right, people will return to

\section{Box 2. SKAU (Letter of Origin)}

Ministerial Decree No. P.51/Menhut-II/2006 requires that all forest products harvested on land legally claimed by a private individual or company have a Letter of Origin or Surat Keterangan Asal Usul (SKAU), before they can be transported.

The Decree requires that the SKAU be issued by a village head or government official equal to the level of village head. The District Head (Bupati) or City Mayor has the authority to appoint the issuer based on a proposal from the Head of the District Forest Service.

In some districts in Central Kalimantan, the village head issues the SKAU which is an easy, quick and not too expensive process. In West Kutai, the SKAU is issued by the District Forest Service. Obtaining the SKAU in West Kutai requires at least a day and an official payment of IDR 30,000 per ton, but reportedly traders pay between IDR $1,300,000$ and $1,400,000$ per truck, or about IDR 145,000 per ton.

Several interviewees raised the question why rattan should be taxed through the Ministry of Forestry. Because in West Kutai nearly all rattan is planted, most consider it an agricultural not forest product.

Agricultural products such as rubber pay a levy to the Dinas Pendapatan Daerah of IDR 150,000/ truck, or less than one tenth of what is paid for rattan. This makes it important to determine whether rattan should be considered a forest or agricultural product.

their gardens and once again maintain them and harvest their rattan. Presently prices are around IDR $1,500 / \mathrm{kg}$ wet sega, and a $30 \%$ increase to IDR 2,000 would get people back into their gardens to harvest.

\section{Rattan traders in Samarinda}

Rattan trade was at its peak between 1980 and 2000 , but presently it is about " $17 \%$ " of what it used to be. Previously, some 20-30 species of rattan were sold to the Javanese, but no longer. Recently one major trader shut down his rattan 
warehouse in Samarinda. The demand from Java is insufficient and only serves about $25 \%$ of the total production potential in East Kalimantan. The present export quotas are far too limited as they only relate to two species. Because of the export bans and quotas, rattan is rotting in the forest and gardens. Also, the furniture producers are suffering; only about $30 \%$ of Cirebon's producers are still in business.

One trader said that it is a misconception that rattan export from Samarinda is not allowed. It can be arranged legally through the right channels, but so far no one has bothered to make the effort.

Another trader mentioned the significant costs of transporting rattan, with several checkpoints on the road between Surabaya and factories requiring payments of "several million rupiah" (several hundred US dollars) per truck.

There appears to be significant illegal trade in rattan. One trader mentioned that Indonesia is importing cheap rattan furniture from China, but with China producing very little, if any, rattan itself. This raises the question of how much (smuggled) Indonesian rattan was used in the first place. Note that official trade data from UN Comtrade support this allegation, but with China having exported only about 100 tons of rattan furniture to Indonesia in 2009, the trade may not be as extensive as suggested. According to the interviewee, smuggling apparently happens from Java by half-filling containers with rattan furniture and the remainder with hidden raw and semi-processed rattan. This load is then sent to Japan and China. Another trader mentioned that Chinese buyers now come directly to East Kalimantan to negotiate deals with local traders or farmers. They arrange export to China through an exporter in Java.

One interviewee recommended that the government [of Indonesia] consider how China can produce rattan furniture more cheaply than Indonesia. He claimed that Indonesia's preference for taxes and tariffs, and high transaction costs because of corruption, made their international rattan trade uncompetitive. However, one trader did not believe that policy and export regulations had an impact on the rattan price. He said ultimately the prices are determined by demand (overseas and domestic).
There were also comments about the risks of the oil palm and coal industries for rattan trade. One interviewee said, "If the government does not get on top of oil palm and coal, rattan will be dead soon." He went on to say that the government has the responsibility to control these industries and maintain a healthy environment: 'They need to be brave enough to prohibit further oil palm and coal mining expansion'.

\section{Rattan traders in Java}

The industry in Java is in decline, with $60-70 \%$ of the local rattan traders having gone out of business in the past few years. One rattan trader in Cirebon who supplies the local furniture industry suggested that the main reasons for the decline in furniture exports were the high rupiah relative to the US dollar and the high price of oil, which reduced profit margins. There has also been a shift in the market to synthetic rattan, with some traders exporting $80 \%$ synthetic products versus $20 \%$ natural rattan ones.

Government ineptness regarding rattan was seen as a serious obstacle, with interviewees saying that few people in the national government had sufficient understanding of the dynamics of the rattan market and industry.

Several traders said that lifting the export quotas would be a very bad idea, as it would reduce national rattan prices and allow competitors such as China to profit. Others suggested that the export quotas are simply a convenient tool to allow traders in Sulawesi, Sumatra and Kalimantan to illegally export vast amounts of unprocessed rattan to China, Taiwan and Singapore. Custom officers cannot tell the difference between different types of rattan, and no one checks whether volumes recorded on paper match what was in the container. Underreporting of half the container contents is common. Presently, most of the high-quality rattan is thought to go to China and other rattan-importing countries, with the poorerquality rattan staying behind in Indonesia.

\section{Cottage industries and rattan shops in Java}

One small-scale rattan furniture producer mentioned that the rattan supply was a major constraint to his ability to fulfil demand for furniture. Quite often 


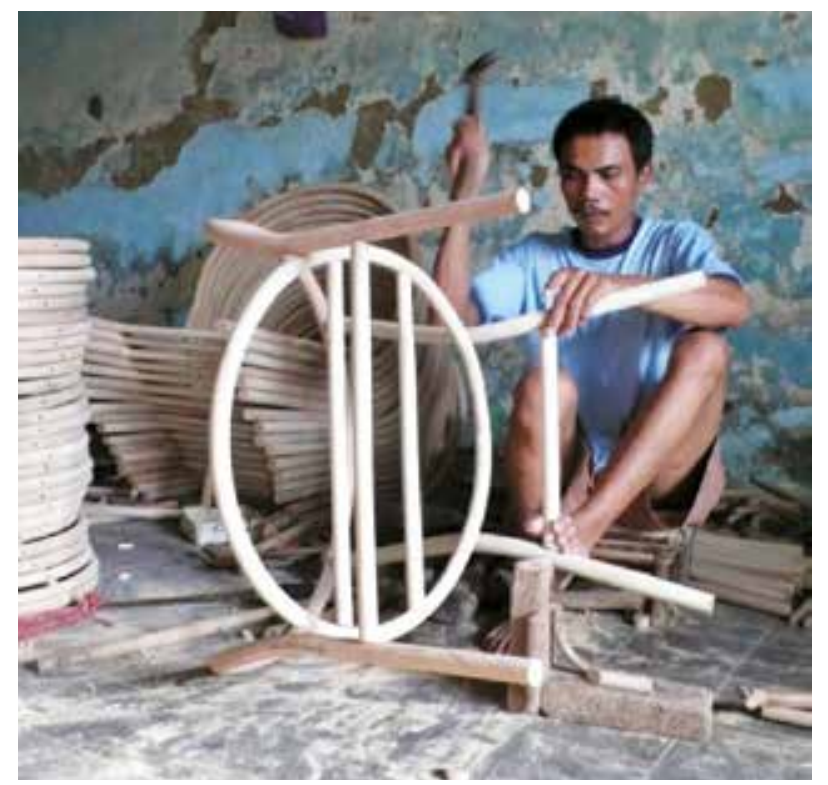

his company would wait for several weeks for a particular rattan order to be delivered, which meant that there was no work for his furniture workers. The workers are paid IDR 3,000 per chair and can produce about 10 chairs per day, earning them approximately USD 3.45/day. We discussed the use of nails in the production of chairs, which international furniture buyers apparently do not like because the nails stain the rattan after exposure to rain. The furniture makers were aware of this problem and said they had the skills to work with wooden plugs rather than nails, but that furniture buyers had requested the use of nails because the end product was cheaper.

One storeowner reported that international demand had increased somewhat, and he expected there to always be demand for rattan. The present fashion of producing furniture with synthetic rattan was unlikely to last, and buyers would always return to natural fibers.

\section{Large furniture traders and makers}

The international export of natural rattan furniture has been much reduced in recent years, with all producers mentioning a 10 -fold or higher decline in the number of monthly containers transported. They mostly blamed this on Sulawesi rattan exporters selling directly to overseas rattan furniture producers rather than domestic ones.
Indonesia is an expensive country to work in. Terminal Handling Charges (THC) for containers in Indonesia are USD 200/container, compared with a reported USD 15/container in Vietnam. China has relatively lower wages, and its taxes and tariffs are also lower than in Indonesia.

Furniture producers had different views about their strength compared with producers in China. Some thought that in Java, production was more flexible because it involved many cottage industries. When big orders came in, the Java industry could easily find many small-scale local producers to increase competition. In China, production is apparently more factory based, which reduces the flexibility.

What Indonesia lacks, however, is an optimization process in furniture production. Everyone seems to make the same models, using the same source products, thus creating high demand for a specific section of total supply potential. It was alleged that in China and Taiwan, the producers were smarter in matching production of certain types of furniture with the temporary availability of certain types and diameters of rattan. Also, in China, there were many more specialized producers, all of which supplied a particular part of the furniture industry. For example, some companies produced readymade and shaped aluminum frames that they sold to furniture makers, whereas in Indonesia the furniture makers had to buy straight aluminum and then shape it themselves to suit their requirements.

\section{Natural rattan versus synthetic fibers and Lloyd Loom}

Natural rattan is increasingly being replaced by other fibers, including natural fibers from banana leaf and other plants, and synthetic ones. Compared with natural rattan, resin whicker made of synthetic polyethylene fibers is more durable and more resistant to the sun's UV rays and to humidity and water. However, it is also more expensive and less comfortable. The Lloyd Loom process was invented in 1917 by the American Marshall B. Lloyd, who twisted kraft paper round a metal wire, placed the paper threads on a loom and wove them into what was to become the traditional Lloyd Loom fabric. 


\section{Rattan importers in Europe and the USA}

Two email replies from importers of rattan furniture in the Netherlands (out of 15 sent) offered some suggestions on how the Indonesian rattan market is changing. One importer, who obtains $100 \%$ of imports from Indonesia, mentioned that his business had not been negatively impacted by trade bureaucracy. The main reason for the decline in the trade in Indonesian furniture was reduced demand in the Netherlands. "Indonesia makes beautiful rattan products, but many of them are completely unsuitable for the European market," he wrote. Large furniture retailers preferred to buy synthetic products from China, which had led to an image change, with natural rattan now seen as oldfashioned. The fact that raw materials can only be imported in small amounts is not a problem, with wages so high in the Netherlands, all furniture production had stopped after 1990.

Interestingly, a rattan importer in Singapore said that they are closing their rattan business because of the lack of rattan supplies from Indonesia.

\section{Local government in Kalimantan}

One local government representative in Kalimantan called rattan the "prima donna" of the non-timber forest products. Rattan has considerable potential because large areas of planted and wild rattan remain, but prices are too low. Prices are kept low by the "Cirebon monopoly" and export quotas. West Kutai does not have an export quota and can therefore sell only to Java and Bali. Prices would definitely rise if exports of semi and unprocessed rattan were to be opened. According to one official, most rattan in West Kutai is on forest estate land for non-forest use (KBNK = Kawasan Budidaya Non Kehutanan). It is presently losing out to rubber because of the high rubber prices and because rattan production is a lot more labor intensive. Another problem for local rattan markets is the large number of road checkpoints (up to 20 or 30 between source and Javanese factories), which increases the transportation costs. This problem could be reduced if East Kalimantan had its own export harbor.

Presently, the local government in West Kutai has limited interest in the rattan industry. Its main source of income from rattan is through the SKAU, which is a transportation levy for goods produced on or harvested from forest estate land, and is meant to control the transportation of forest products. The official levy for rattan is $6 \%$ of IDR 500,000/ton = IDR 30,000/ton of sega rattan, but higher for the more expensive rattan species. Unofficial prices to obtain a SKAU, mentioned by various people, range from IDR 1,300,000 to IDR $1,400,000 /$ truck. One official suggested that the SKAU levy, which was determined in 2007, should be more flexible and reflect actual market prices. With very low rattan prices, rattan farmers and traders are hit relatively hard by SKAU levies.

The officially reported trade volume of rattan from West Kutai was 615 tons in 2009 and 144 tons in 2010. One trader interviewed, who always obtained the SKAU, said that in 2009 alone he had transported some 1100 tons out of West Kutai. This amount exceeds the recorded annual total for the district by 500 tons, suggesting that most trade goes unreported. We know that other traders were also transporting rattan out of the district in 2009, increasing the discrepancy between recorded and actual traded volumes. This suggests that much rattan transportation goes unrecorded because either the required Letter of Origin (SKAU) is not obtained or the traded volumes with SKAU are not accurately recorded by the district forestry service.

There are plans to rehabilitate degraded lands with NTFPs, such as gaharu (Aquilaria malaccensis), rattan and sugar palm (Arenga spp.). The role of the district forestry service is to promote this program, but they neither have activities nor do they supply seeds to help the program.

District forestry staff in West Kutai told us that the major threat to West Kutai's rattan industry is the coal-mining industry, because people sell their land rather than trying to harvest cheap rattan. From a biodiversity perspective, rattan beats any other non-forest crop, but financially it loses. Rattan certification has been considered, but the transaction costs would be far too high, and it would be difficult to market rattan as a forest product. Government staff suggested that for the future of rattan, the market needs to be more open, and it would be better if rattan export quotas were lifted. Considering global demand, rattan prices should be the same as rubber prices. 


\section{Local government in Java}

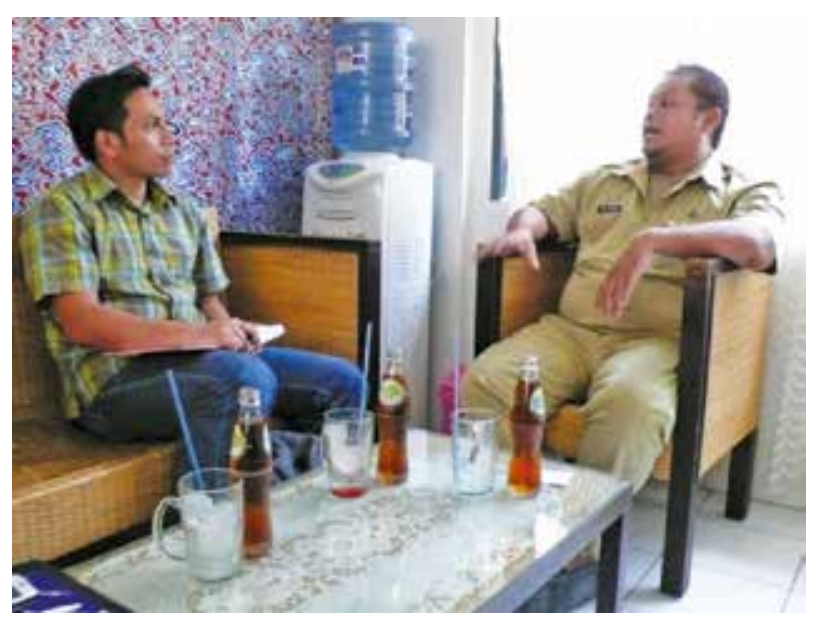

There is a significant shortage of rattan supply in Cirebon. The furniture industry needs about 70,000 tons per year but it receives only 35,000 tons. This decline started in 2009 and further deteriorated in 2010. Local government officials attribute the shortage of rattan supplies to the furniture industry primarily to the export quotas, which have not helped to boost farmgate prices, but have significantly increased legal and illegal exports. According to them, smuggling occurs primarily from Palu in Sulawesi, and until 2007, also from Tanjung Priok harbor in Jakarta. Apparently, it is now cheaper to buy rattan in Singapore (originating from Indonesia) than in Indonesia itself, with an estimated $80 \%$ of Singapore's rattan allegedly being illegally imported from Kalimantan (some through Entikong in Sarawak, Malaysia) and Sumatra. The Indonesian rattan trade is hampered by a lack of information flow between the rattan producers and the domestic consumers. We discussed the option of developing an online trading or auctioning system, but they said there would be a problem with settling payments with ensured delivery of products. A system would be required in which buyers can make down payments, knowing that they cannot lose their money, and sellers make the rattan delivery confident that they will get paid.

\section{ASMINDO}

The ASMINDO people we talked to presented a variety of opinions, depending on where their own business interests lay. ASMINDO representatives in East Kalimantan were more in favor of opening up the export of unprocessed and semi-processed rattan, whereas those directly involved with the furniture industry or Javabased rattan trade wanted a complete export ban. Feelings about the export quotas are quite strong, with representatives in Java thinking that the export quotas have ruined the industry. It is worth noting that the ASMINDO perception that the ban caused the decline in exports is not supported by Cirebon's own export data (see Figure 11). ASMINDO emphasizes the added value of the furniture industry, with 1 container of furniture requiring 3 tons of rattan and providing work for 60 furniture makers. They ask why countries other than Indonesia should obtain these benefits.

The competition from China is keenly felt in Cirebon. The Chinese industry is helped by government support, fewer bureaucratic requirements and lower VAT. One interviewee pointed out that Indonesia's VAT is $10 \%$ and that although in theory it should be possible to get this reimbursed when exporting, in reality this is very hard. The problem is therefore not that China can produce rattan goods more efficiently than Indonesia, but that it can do it much more cheaply and sell at a price $60 \%$ below Indonesia's average market prices.

Another problem is price fixing through Indonesian trade cartels. In theory, furniture producers and rattan traders in Java could increase the farm-gate price, but traders in Sulawesi and Kalimantan prevent that from happening. It is not clear how exactly this is happening and who is involved, but one interviewee told of an instance when he had tried to buy directly from Central Kalimantan and had agreed on a good price, but then later was told by the farmers that the deal could not go through and that they had had to sell to another trader. Apparently these trade cukong determine the price within their cartel and ensure that anyone trading outside their range is prevented from buying rattan.

The Indonesian government needs to more effectively promote the rattan industry through International Trade Promotion (a program run through the Indonesian embassies). ASMINDO receives funding from the Ministries of Trade, Industry and Forestry to promote rattan overseas, 
but it wants more effective promotional programs. ASMINDO continues to lobby the government to cancel the present export quotas and ban all export of unprocessed and semi-processed rattan. The Ministries of Forestry and Industry are in favor of such a ban, but the Ministry of Trade is not.

\section{NGOs dedicated to rattan}

One of the most active NGOs in East

Kalimantan's rattan industry was SHK. They obtained a $€ 2.5$ million grant (ca. USD 2.3 million based on 2000 rate) from the EU in 2000 for district-level work on rattan in West Kutai. Among others, SHK set up a rattan-splitting factory, a rattan farmers and craftsmen association (PPPR), and a microcredit facility. However, the grant was withdrawn because of mismanagement of funds in 2005; SHK stopped all activities in 2007, and closed down officially in 2010. The rattan-splitting facility is no longer used, although the building remains in use by a commercial rattan trader to prepare semi-processed rattan (Figure 15). Its failure had to do with the price of semi-processed rattan, which was not high enough to justify the extra expenses of processing the rattan locally. In addition, local workers did not have the same skills as their Javanese counterparts, and so products were lower quality and fetched lower prices. A local factory is therefore no longer considered possible, for both commercial and socio-cultural reasons.

A former member of PPPR, the now mostly defunct rattan farmers association in West Kutai set up by SHK, said that local rattan farmers are no longer interested in organizing themselves into associations. The main reason is that trade is down because of low rattan prices. People no longer maintain their rattan gardens because they can obtain higher revenues from rubber, fish and bushmeat, or they sell their land to oil palm or coal-mining companies. The production of rattan products such as mats and baskets, which was once common in the area, has stopped altogether. In the 1980 s, there were government subsidies for skills development for production of such handicrafts but it was poorly organized and eventually died out. There is no local motivation to do this kind of handicraft work.

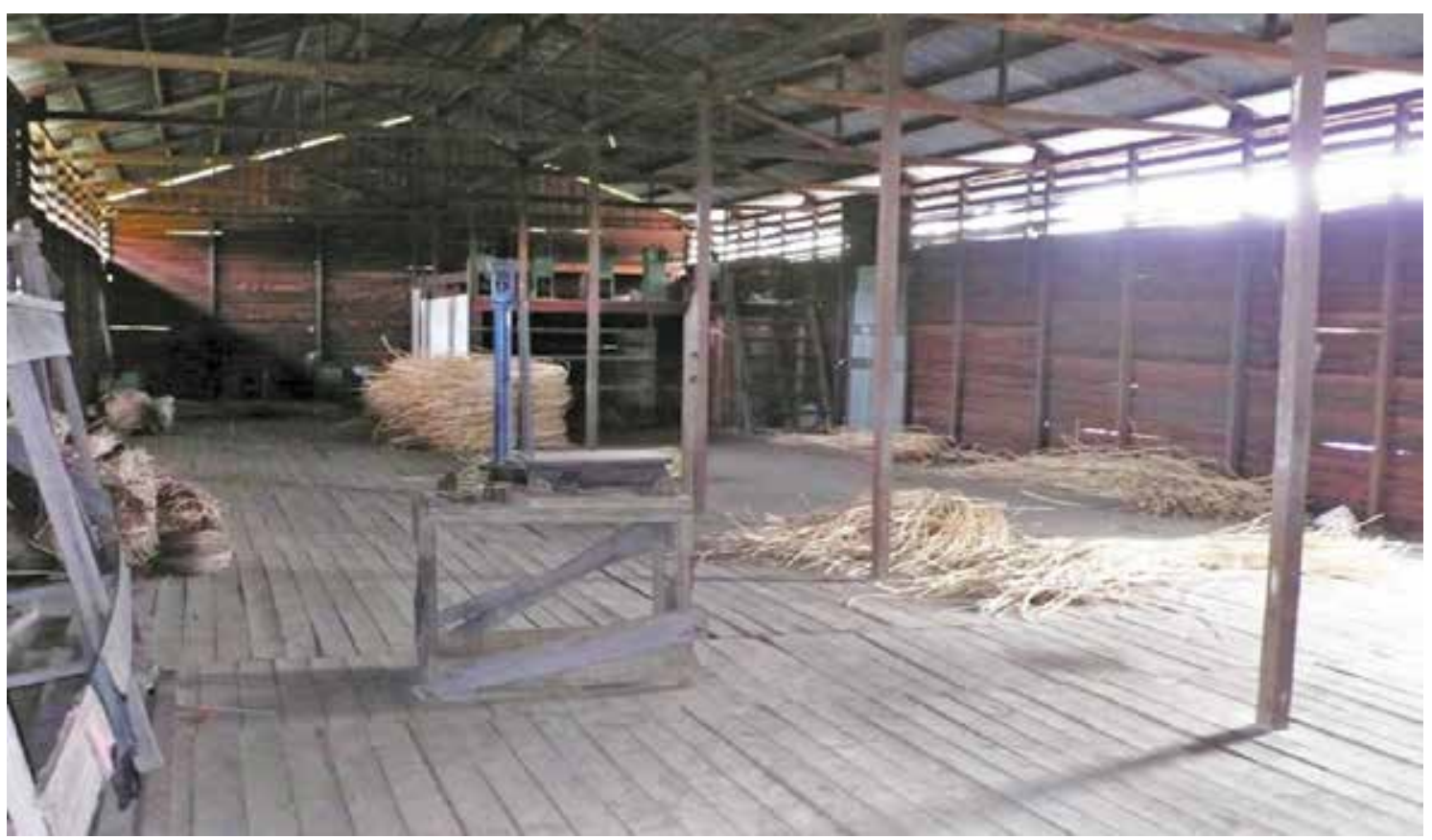

Figure 15. Rattan splitting factory in Jengan Danum, West Kutai, with rattan splitting machines in the background (February 2011). 

CIFOR Occasional Papers contain research results that are significant to tropical forest issues. This content has been peer reviewed internally and externally.

We investigated the production and trade in rattan along the supply chain. We focused our study on Indonesia, the global leader in natural rattan production, and more specifically, West Kutai in East Kalimantan. Our analysis of local livelihoods in 2004 and 2011 indicates that communities have abandoned rattan as their main source of income, primarily because of low rattan farm-gate prices. Our interviews and econometric analysis indicate that rattan prices are kept artificially low through price fixing within a cartel of rattan traders. Farm-gate prices are also kept low by export quotas. The result has been a substantial reduction in export volumes of Indonesian rattan products (as opposed to unprocessed and semi-processed rattan). Other contributing factors include reduced overseas demand, the relative strength of the rupiah and the loss of Indonesia's competitive edge over other countries. Compared to its competitors, Indonesia has higher transaction costs, including taxes, tariffs, administrative costs and transportation costs. We conclude that a lack of reliable data on rattan resources and unstable policy have hampered efforts to develop sustainable management strategies and annual allowable harvest volumes. We recommend the development of a national rattan action plan, based on reliable scientific data. This would require more accurate information on rattan trade, future development in the rattan products market, production capacity in forests and planted rattan gardens, and international trade, including illegal trade. such information could guide rattan policies, specifically determining what trade legislation would have the best macro and microeconomic results for Indonesia.

\begin{tabular}{|c|c|c|}
\hline CGIAR & $\begin{array}{l}\text { RESEARCH } \\
\text { PROGRAM ON } \\
\text { Forests, Trees and } \\
\text { Agroforestry }\end{array}$ & $\begin{array}{l}\text { This research was carried out by CIFOR as part of the CGIAR Research Program on Forests, Trees } \\
\text { and Agroforestry (CRP-FTA). This collaborative program aims to enhance the management and } \\
\text { use of forests, agroforestry and tree genetic resources across the landscape from forests to farms. } \\
\text { CIFOR leads CRP-FTA in partnership with Bioversity International, CATIE, CIRAD, the International } \\
\text { Center for Tropical Agriculture and the World Agroforestry Centre. }\end{array}$ \\
\hline
\end{tabular}

cifor.org

blog.cifor.org 